The research program of the Center for Economic Studies (CES) produces a wide range of theoretical and empirical economic analyses that serve to improve the statistical programs of the U.S. Bureau of the Census. Many of these analyses take the form of CES research papers. The papers are intended to make the results of CES research available to economists and other interested parties in order to encourage discussion and obtain suggestions for revision before publication. The papers are unofficial and have not undergone the review accorded official Census Bureau publications. The opinions and conclusions expressed in the papers are those of the authors and do not necessarily represent those of the U.S. Bureau of the Census. Republication in whole or part must be cleared with the authors.

DEMOCRATIZING ENTRY:

\title{
BANKING DEREGULATIONS, FINANCING CONSTRAINTS, AND ENTREPRENEURSHIP
}

by

\author{
William Kerr * \\ Harvard Business School \\ and \\ Ramana Nanda * \\ Harvard Business School
}

CES 07-33 December, 2007

All papers are screened to ensure that they do not disclose confidential information. Persons who wish to obtain a copy of the paper, submit comments about the paper, or obtain general information about the series should contact sang V. Nguyen, Editor, Discussion Papers, Center for Economic Studies, Bureau of the Census, 4600 Silver Hill Road, 2K132F, Washington, DC 20233, (301-763-1882) or INTERNET address sang.v.nguyen@census.gov. 


\begin{abstract}
We study how US branch-banking deregulations affected the entry and exit of firms in the non-financial sector using establishment-level data from the US Census Bureau's Longitudinal Business Database. The comprehensive micro-data allow us to study how the entry rate, the distribution of entry sizes, and survival rates for firms responded to changes in banking competition. We also distinguish the relative effect of the policy reforms on the entry of startups versus facility expansions by existing firms. We find that the deregulations reduced financing constraints, particularly among small startups, and improved ex ante allocative efficiency across the entire firm-size distribution. However, the US deregulations also led to a dramatic increase in "churning" at the lower end of the size distribution, where new startups fail within the first three years following entry. This churning emphasizes a new mechanism through which financial sector reforms impact product markets. It is not exclusively better ex ante allocation of capital to qualified projects that causes creative destruction; rather banking deregulations can also "democratize" entry by allowing many more startups to be founded. The vast majority of these new entrants fail along the way, but a few survive ex post to displace incumbents.
\end{abstract}

JEL Classification: E44, G21, L26, L43, M13.

Key Words: banking, financial constraints, entrepreneurship, entry, exit, creative destruction, growth, deregulation.

* Comments are appreciated and can be sent to wkerr@hbs.edu and rnanda@hbs.edu. We are grateful to Rodrigo Canales, Nicola Cetorelli, Shawn Cole, Jim Davis, Ed Glaeser, Victoria Ivashina, Ron Jarmin, Josh Lerner, Javier Miranda, Steve Ross, David Scharfstein, Antoinette Schoar, Jesper Sorensen, Phil Strahan, Rebecca Zarutskie and seminar participants at the Census Bureau, Kellogg, Harvard, IPE, MIT, New York FRB, NBER, Reserve Bank of India, and the University of Connecticut for insightful comments on this paper. We also thank the Innovation Policy and the Economy group for financial assistance. The research in this paper was conducted while the authors were Special Sworn Status researchers of the U.S. Census Bureau at the Boston Census Research Data Center (BRDC). Support for this research from NSF grant (ITR-0427889) is gratefully acknowledged. Research results and conclusions expressed are our own and do not necessarily reflect the views of the Census Bureau or NSF. This paper has been screened to insure that no confidential data are revealed. 


\section{Introduction}

The financial sector's role for driving economic growth and development has received increasing attention in recent years, with several authors articulating a positive relationship between financial development and economic growth at the cross-country level (e.g., Beck et al. 2000; Levine 1997; Levine et al. 2000). This research argues that better financing environments are associated with higher economic growth, at least in part, because they facilitate better allocation of capital across investment opportunities, thereby promoting entrepreneurship and the Schumpeterian process of creative destruction (e.g., King and Levine 1993a,b; Rajan and Zingales 2003; Aghion et al. 2007; Bertrand et al. 2007).

Despite the wealth of cross-country research, however, there are few empirical studies that directly examine how changes in financial markets impact the entry and exit of firms in product markets (e.g., Black and Strahan 2002; Cetorelli and Strahan 2006; Zarutskie 2006; Bertrand et al. 2007). ${ }^{1}$ Understanding the micro-mechanisms through which the financing environment impacts industry structure and economic growth is particularly important given that theoretical models relating financial development to product market outcomes often yield ambiguous, or even opposing, predictions. ${ }^{2}$

This paper studies how the US banking deregulations that lifted local banking monopolies from the late 1970s through the early 1990s impacted entrepreneurship and industry structure in non-financial sectors. The structure of the banking industry is a major influence on the financing environment faced by firms, with bank debt comprising up to $60 \%$ of their total borrowings (e.g., Petersen and Rajan 1994). Small businesses, and new ventures in particular, rely heavily on banks for financing their operations as they have fewer outside sources of financing (e.g., Berger and Udell 2002; Fluck et al. 1998). Reducing distortions in the banking sector, such as lifting local monopolies in banking markets, can therefore have first-order effects on product market outcomes.

We examine how the entry rates, the distributions of entry sizes, and the survival rates for firms in product markets responded to changes in banking competition. We employ detailed establishment-level data collected by the US Census Bureau that annually tracks every US private-sector establishment from 1976 to 1999. While our study is most closely related to Black and Strahan (2002) and Cetorelli and Strahan (2006), three particular advantages of these data facilitate a more detailed examination of the mechanisms through which the deregulations

\footnotetext{
${ }^{1}$ Most research examining financing constraints focuses on established firms (e.g., Banerjee and Duflo 2004; Fazzari et al. 1988; Kaplan and Zingales 1997, 2000; Moyen 2004; Paravisini 2005) or the transition of individuals into entrepreneurship (e.g., Evans and Jovanovic 1989; Gentry and Hubbard 2000; Hurst and Lusardi 2004).

${ }^{2}$ Levine (1997) outlines the ambiguous predictions of enhanced liquidity on economic growth. Black and Strahan (2002) outline two opposing channels through which banking deregulations impact entrepreneurship.
} 
affected entry and exit. First, the data cover all US establishments, including private firms, small businesses, and 'micro' establishments of one or more individuals. We can thus characterize better the impacts of the reforms across the entire firm-size distribution. These better data are especially true for the very small startups that are likely to be most affected by capital constraints for entry but are often excluded or subsampled in large-scale datasets.

Second, the panel nature of the data allows us to track individual establishments over time. This feature allows us to separate analyses of entry rates (i.e., the extensive margin) from estimations of changes in entry sizes (i.e., the intensive margin). We do so through studies of the entry-size distribution and of the size of entrants in their first year compared to subsequent growth within establishment. This delineation improves upon aggregate metrics like average entry size that confound the two margins. ${ }^{3}$ The panel structure also affords a detailed study of survival rates for new entrants, which again can be considered at different points in the entry-size distribution.

Third, we can separate new establishments into startups and additional facilities being opened by existing firms. This feature allows us to compare how the banking deregulations impacted the entry and exit of startups - that, in general, face greater financing constraints - to the entry and closure of plants by multi-unit firms. In addition to having substantive value, this distinction is also valuable from an econometric standpoint as it allows us to control for a greater set of omitted variables than prior studies. By using the facility expansions of existing firms as a 'within state-industry-year' baseline against which to compare the founding of new ventures, we are able to control both for annual changes in the overall entry rates of startups versus existing firms and for aggregate entry conditions at the state-industry-year level. Our identification strategy therefore isolates the impact that changes in the financing environment have on entrepreneurship over-and-above the increase in facility expansions by existing firms. ${ }^{4}$

Similar to Black and Strahan (2002), we find that the interstate banking deregulations led to a substantial increase in the entry rates of startups. Our work further demonstrates that startups exhibited a greater increase in entry than facility expansions and that this effect was particularly strong among establishments entering with 20 employees or fewer. Moreover, for those firms that survived at least three years, startups entered at larger sizes relative to new establishments of existing firms. These results provide compelling evidence that the deregulations reduced financing constraints and that startups - which tend to have fewer sources of external finance

\footnotetext{
${ }^{3}$ Lower financing constraints may facilitate larger entry sizes for firms that would have entered regardless (e.g., Evans and Jovanovic 1989; Cabral and Mata 2003), an intensive margin effect that would promote higher average entry sizes. If the deregulations also influence entry rates, however, average entry sizes will capture changes on both the intensive and extensive margin (e.g., greater entry at the bottom of the size distribution that decreases average entry size).

${ }^{4}$ We also provide new evidence regarding the dynamic patterns of entry and exit in the non-financial sectors after the banking deregulations, which suggests that effects on the product market were a consequence of the reform rather than causing them.
} 
and hence are more sensitive to reductions in interest rates or credit rationing - benefited more from the deregulations than existing firms.

We also find that the increase in startup activity relative to facility expansions is present, albeit smaller, at the higher end of the size distribution. Since firms that are entering at over 100 employees are not as likely to be credit constrained on the extensive margin, this finding is consistent with the view that deregulation improved allocative efficiency across the firm-size distribution, so that good investment ideas of startups were more likely to be financed despite the fact that they were not 'insiders' or privileged clients (e.g., Jayaratne and Strahan 1996; Laeven 2000; Rajan and Zingales 2003; Bertrand et al. 2007).

The most striking feature of the US deregulations, however, was the dramatic increase in the entry of establishments that failed within three years. This 'churning' was particularly strong for small firms. For example, startup establishments entering with 6-20 employees experienced an over 30\% increase in churning relative to facility expansions of multi-unit firms. This strong increase in churning following the deregulations cannot be explained solely within a model of better ex ante allocation of capital to qualified projects. Rather, another channel through which banking competition facilitates the process of creative destruction is to allow many more startups to be founded, only some of which survive ex post to displace eventually incumbents. This process suggests that the relative impacts of banking deregulation on entrepreneurship may far exceed impacts on the displacement of incumbents, which we show to be consistent with the US experience.

Our findings are relevant to the developing empirical literature documenting how reforms to the banking sector may positively impact the real economy through the reallocation of resources in non-financial sectors (e.g., Bertrand et al. 2007; Cetorelli and Strahan 2006; Cetorelli 2004). This study not only provides further evidence that well functioning capital markets strengthen entrepreneurship in local economies, but also better characterizes the mechanisms surrounding this entry. Most importantly, deregulation may facilitate creative destruction through the 'democratization' of entry rather than just through ex ante allocative efficiency. These results complement Bertrand et al.'s (2007) study of the French banking deregulations' impact for firms with over 100 employees.

Our results also complement prior research examining the relationship between banking structure and lending to existing small businesses (e.g., Petersen and Rajan 1994; Berger and Udell 1995). Although the theory is ambiguous as to whether concentrated banking markets are good for entrepreneurship, our results support the view that more competitive banking markets have a positive effect on the entry of small, financially constrained firms (e.g., Erel 2006; Berger et al. 2005; Black and Strahan 2002). However, our findings on churning paint a richer portrait of how banking deregulations impact product markets. 
The rest of the paper is structured as follows. Section 2 provides a more detailed description of the theoretical considerations and our empirical approach. The third section introduces the Longitudinal Business Database (LBD) and compares the aggregate entry behavior of startup firms and multi-unit facility expansions. We report our panel estimation results on the entry rates, entry sizes, survival, and churning of new establishments in Section 4. Sections 3 and 4 also provide new evidence from the LBD regarding changes in banking structure following the deregulations. In Section 5, we conclude our study by identifying further how our results fit into the literature and the areas for future research.

\section{Theoretical Considerations and Estimation Design}

Our empirical approach exploits cross-state variation in the timing of branch banking deregulations in the US. The 1970s through the mid 1990s experienced a significant liberalization in the ability of banks to establish branches and to expand across state borders (either through new branches or acquisitions). Prior to these liberalizations, banks faced multiple restrictions on geographic expansion both within and across states.

The McFadden Act of 1927 required national banks to obey state-level restrictions on branching, effectively prohibiting cross-state branch banking. In addition, many states developed stringent rules governing the conduct of branch banking within their territories. The most restrictive of these, known as unit banking, limited each bank to a single branch. Although banks responded to these restrictions by forming multibank holding companies (MBHCs) that owned more than one bank, states in turn restricted the activities of MBHCs. Restrictions on intrastate branching for MBHCs focused on the market share and concentration of these holding companies, while the Douglas Amendment of 1956 prevented a MBHC from owning banks across state borders.

As shown in Figure 1, only 12 states had some form of intrastate branch banking deregulation prior to 1970, and no state allowed interstate branch banking. Starting in the 1970s, and especially in the 1980s, most states passed laws deregulating the restrictions on the ability of banks to open or acquire new branches. Two classes of restrictions were eased over this period. First, intrastate deregulations for branch banking allowed banks to expand within the passing state either by acquiring other bank branches or by setting up new bank branches themselves. This allowed for more competition in the local banking market, in some cases even breaking-up effective monopolies that existed prior to these liberalizations. ${ }^{5}$

\footnotetext{
${ }^{5}$ The intrastate branch banking deregulations consist of two elements. The first deregulation allows banks to expand within states through mergers and acquisitions. The second allows banks to open de novo branches. We focus on the leading edge of these intrastate reforms in this paper.
} 
Second, interstate branch banking deregulations allowed banks to acquire branches in other states with which their 'home state' had negotiated such a bilateral agreement. This class of reforms further reduced the monopoly power of local banks, in particular due to the significant improvements in the market for corporate control (e.g., Berger et al. 2001). ${ }^{6}$ In part due to reciprocal nature of these agreements, most states undertook interstate deregulations in the mid 1980s to early 1990s. These state-level reforms culminated in the Riegle-Neal Interstate Banking and Branching Efficiency Act of 1994, which overturned the McFadden Act and allowed national interstate branch banking after 1995. In effect, the Riegle-Neal Act put out-of-state banks on par with local banks in every state, with important implications for capital reserves and banking efficiency across the industry. ${ }^{7}$

The period following the liberalization of interstate branch banking led to an expansion of the large MBHCs across state borders and a significant fall in the number of small local banks. Table $1 \mathrm{~A}$ documents aggregate changes in the banking sector taken from the LBD. The total number of banks fell by 30\% from the mid-1970s to the mid-1990s. The share of large banks, defined as having more than 500 employees, and the share of branches controlled by large banks increased over the same period. There was also a sharp increase in the share of branches controlled by out-of-state banks, growing from $2 \%$ to $25 \%$, suggesting a robust market for corporate control across state borders. ${ }^{8}$

Our findings on the changes in the banking industry using the LBD data mirror those using bank assets rather than bank employees as a metric for bank size. For example, Berger et al. (2001) find that the fall in the number of banks is almost completely accounted for by the reduction in small banks with assets under $\$ 100 \mathrm{~m}$. Moreover, they find that the percentage of industry assets managed by 'megabanks' (i.e., with more than $\$ 100 \mathrm{~b}$ in assets) almost doubled from 1977 to 1994 . The percentage of industry assets managed by small banks, on the other hand, halved over the same period.

The increase in banking competition and strengthening of the market for corporate control due to the deregulations are thought to have improved allocative efficiency by allowing capital to flow more freely towards projects yielding the highest returns and to more efficient producers. Moreover, although the number of banks fell over this period, the number of bank branches increased considerably, reflecting greater competition and increased consumer choice in local

\footnotetext{
${ }^{6}$ The interstate deregulations may have also improved economies of scale, although Berger et al. (2001) argue that the mergers resulted in few cost savings on average.

${ }^{7}$ The Riegle-Neal Act opened up nationwide acquisition of banks across state lines so that a bank in any state could acquire another bank in any state, regardless of whether their respective 'home states' had negotiated an agreement allowing cross-state acquisitions (unless a state explicitly opted out). In addition, the Riegle-Neal Act allowed banks to set up new branches across state borders without the need to acquire a subsidiary bank, and MBHCs could convert subsidiaries into branches. Kane (1996) carefully discusses the Riegle-Neal Act.

${ }^{8}$ The financial sector is less precisely measured than product markets in the LBD prior to 1992 . These banking statistics, nevertheless, are indicative of the substantial shifts in the sector's structure during this period. See also Berger et al. (2001) and Janicki and Prescott (2006).
} 
markets. From a theoretical perspective, these reforms could have had a strong positive effect on entrepreneurship if startups face substantial credit constraints. Moreover, since entrepreneurs have fewer non-bank options for financing their projects relative to existing firms (e.g., internal cash flow, bond markets), more efficient allocation of capital within the banking industry should lead to larger increases in startup entry relative to facility expansions by existing firms.

However, there are two theoretical reasons why these reforms may instead harm the entry of startups. First, Petersen and Rajan (1995) argue that startups benefit from concentrated banking markets because a monopolist bank can engage in inter-temporal cross-subsidization of loans. As a monopolist bank can charge above-market interest rates to mature firms, they can in turn charge below-market rates to potential entrepreneurs. By doing so, the monopolist bank can maximize the long-term pool of older firms to which they lend. Increased competition weakens the market power of local banks for mature firms, reducing their ability to charge above-market rates, and thereby weakens their incentives for charging below-market rates to new entrants as well.

Second, several studies argue that small banks have a comparative advantage relative to large banks at making lending decisions for startups because they are better at screening on 'soft' versus 'hard' information (e.g., Stein 2002; Berger et al. 2005). If lending decisions in larger banks are based on a more hierarchical decision process, the ultimate adjudication decisions may come from officers who do not know potential borrowers personally. These decisions are more likely to be based on credit scoring models that inherently focus on hard information. On the other hand, local loan officers at small banks know information about borrowers that cannot be condensed into a credit score. This ability to lend and monitor based on soft information may give local loan officers a comparative advantage in lending to entrepreneurs. Since the banking reforms led to a shift in industry structure from small banks towards large banks, this could have had a direct negative effect on lending to startups relative to established firms with a history of audited accounts. On both fronts, therefore, this second set of theories suggest that entrepreneurs may have suffered from the banking deregulations.

As can be seen from Figure 1, the timings of the intrastate and interstate branch banking deregulations are sufficiently different and independent across states that we can jointly investigate the effect of these two reforms on startup entry. We prefer to model the reforms jointly to isolate better their respective impacts, but our results are robust to estimating the effect of the two reforms separately. The intrastate deregulation captures the relative trade-off between allocative efficiency from increased competition and the potential cost to entrepreneurs from a loss of concentrated markets. The interstate deregulation captures the trade-off between these efficiencies and the potential cost to entrepreneurs from the shift away from small banks as a source of small business lending. Our study can therefore also be seen as a test for the presence of financing constraints in entrepreneurship. Since there are several theoretical channels 
through which banking competition may hinder startup activity, evidence of a net increase in entrepreneurship relative to facility expansions of existing firms would indicate a strong, positive benefit to entrepreneurship through increased competition among banks.

We construct tight comparisons of startup entry rates to the facility expansions of existing firms that remove all local conditions common to the two types of entrants. We use the facility expansion comparison, rather than firm growth through employment adjustments at existing plants, to create a baseline with similar discontinuous financing requirements. We further control for aggregate changes in entry rates for both types of firms. This platform is only feasible due to our establishment-level data. Since the cross-state variation in the timing of the reforms may have been correlated with the structure of the banking industry ${ }^{9}$, prior research regarding the effect of these banking deregulations on the non-financial sector relies on interactions between the timing of the reforms and each industry's dependence on external finance to achieve identification (e.g., Cetorelli and Gambera 2001; Cetorelli and Strahan 2006). We go further by exploiting variation across types of entrants within state-industry-year cells. This estimation approach controls for a greater set of omitted factors than earlier work, and we utilize a dynamic model that parses out transitory features of the adjustment process. Most importantly, though, the elasticities of establishment openings for existing firms provide an important benchmark for isolating the relative importance of these deregulations for entrepreneurship specifically.

\section{Longitudinal Business Database}

The data for this study are drawn from the Longitudinal Business Database (LBD). Sourced from US tax records and Census Bureau surveys, the LBD provides annual observations for every private-sector establishment with payroll from 1976 to 1999 . Approximately 3.9m establishments, representing over $68 \mathrm{~m}$ employees, are included each year. As the micro-records document the universe of establishments and firms, rather than a stratified random sample or published aggregate tabulations, the Census Bureau data are an unparalleled laboratory for studying entrepreneurship rates and the life cycles of firms in the US. In addition, the LBD lists the physical location of establishments rather than the location where they are incorpo-

\footnotetext{
${ }^{9}$ Accounts of the political economy of the reforms suggest their passage are mostly exogenous to product markets, driven in part by federal actions and state-level structure of the banking industry. Black and Strahan (2001) argue that some of the impetus for the intrastate deregulations came from initiatives taken by the Office of the Comptroller of the Currency that put banks with national charters on par with Savings and Loans (S\&Ls) and savings banks that could branch freely within states. The interstate deregulations were driven in part by the S\&L crisis in the early 1980s when federal legislators allowed failed banks and thrifts to be acquired by banks in any state, regardless of the state laws governing these transactions. These paved the way for bilateral negotiations between various states to allow interstate banking to capture the benefits of larger, diversified banks that were less susceptible to failure. Kroszner and Strahan (1999) also note that the timing of the reforms are driven in part by the relative strength of banking interest groups that favored the deregulation. These issues are further discussed below. Appendix Table 1 lists each state and the dates of the branch banking deregulations.
} 
rated, which allows us to circumvent issues related to higher incorporations in certain states like Delaware.

The comprehensive nature of the LBD facilitates the development of complete state-industryyear panels of birth counts by type of firm and the distribution of establishment entry sizes (in terms of employment). Each establishment is given a unique, time-invariant identifier that can be longitudinally tracked. This allows us to identify the year of entry for new startups or the opening of new plants by existing firms. ${ }^{10}$ Second, the LBD assigns a firm identifier to each establishment that facilitates a linkage to other establishments in LBD. This firm hierarchy allows us to separate new startups from expansions by existing multi-unit firms.

Publicly available series do not provide birth counts by state-industry cells; even when they do provide approximations based on total employment, the Census Bureau is required to suppress values that compromise the confidentiality of individual establishments. Moreover, the entry of startups versus expansion establishments is not released. Building from the microdata overcomes these limitations. Our data include the manufacturing, services, retail trade, wholesale trade, mining, transportation, and construction sectors from 1977 to $1998 .{ }^{11}$

Table 2 provides descriptive statistics on entrants in our sample. Over $80 \%$ of the 400k new establishments opened in each year are new firm formations. Figure 2 plots the relative entry counts over time of startup establishments and the expansion establishments of existing firms, with entry counts in 1977-1981 normalized to 100\% for each group. While startups constitute the vast majority of new establishments, this time plot demonstrates that the relative increase in startup activity has consistently lagged that of expansion establishments since the early 1980s. There is only a $10 \%$ increase in the raw number of startup entrants over the twenty-year period, despite a $20 \%$ overall growth in LBD employment. Measured in terms of rates, Davis et al. (2006) document a substantial reduction in business entry and exit from the late 1970s to the late 1990s using the LBD. Figure 2 also documents a broad decline in entry during the early 1990s. This is consistent with the decline in credit available to firms during this period (e.g., Berger et al. 2001; Zarutskie 2006).

These aggregate trends are important when interpreting the upcoming panel estimation results. We will control for the aggregate trends of startups and expansion entry by existing firms with separate year fixed effects for each type of firm. These panel effects remove aggregate trends that affect these two groups differently and would otherwise bias the parameter estimates

\footnotetext{
${ }^{10}$ We define entry for a given establishment as the first year that it has positive employment. We do not include exit and re-entry in our birth counts. The data begin in 1976, and we consider entry from 1977 onward.

${ }^{11}$ Jarmin and Miranda (2002) describe the construction of the LBD. Sectors not included in the LBD are agriculture, forestry and fishing, public administration, and private households. We also exclude the US postal service, restaurants and food stores, hospitals, education services, and social services. Finally, we separate the financial services sector for analysis. Incomplete LBD records require dropping 25 state-year files: 1978 (12 states), 1983 (4), 1984 (4), 1985 (1), 1986 (1), 1989 (1), and 1993 (2).
} 
(e.g., different cyclical volatilities for firm formations). These aggregate trends, however, include overall movements in credit access that are partly due to deregulations. The inference of panel estimations using the cross-state banking variation is in part from greater or weaker relative declines in startup entry rates for states that have deregulated versus those that have not.

While startups account for the majority of new establishments, existing firms open new establishments at much larger sizes. New establishments of existing firms start on average with four times the employment of startups. Figure 3 documents the distribution of establishment entry sizes for these types of firms. $76 \%$ of new startups begin with five or fewer employees, versus $44 \%$ for expansion establishments of existing firms. These distributions suggest startups may face constraints on the intensive margin of entry size as well as the extensive margin of entry rates. Looking at the capital-intensive manufacturing sector in Figure 4, the distribution differentials are even more pronounced. There are, however, many other factors that need to be considered in modelling starting establishment size to isolate the role of financing constraints.

Manufacturing accounts for just under $10 \%$ of the total entry; manufacturing, services, wholesale trade, and retail trade jointly account for $75 \%$ of the total entry of new establishments. ${ }^{12}$ Despite the well-documented concentration of high-tech entrepreneurship within regions like Silicon Valley and Boston's Route 128, the broad entry and exit rates we consider are more evenly spread across US regions. There are also no substantial differences in the extent to which startups versus existing firms open new establishments across regions. These geographic regularities aid our using of cross-state variation in banking deregulations to study entrepreneurship, as the results are not overly dependent upon the outcomes of a single state or region. ${ }^{13}$

Table 2 also shows that the aggregate distributions of establishment exits across the size distribution, industries, and geographic regions are relatively similar to entry for the period of study. On the other hand, the rate of 'churning' - defined as establishments that exit within three years of entry - is much larger for startups (46\%) relative to that of established firms $(28 \%)$ and more concentrated at the lower end of the size distribution.

\section{Empirical Results}

This section reports our empirical results regarding establishment entry rates, entry sizes, exit rates, and churning. We begin with state-year panel estimations that separately examine the

\footnotetext{
${ }^{12}$ The exclusion of health, education, social services, and community organizations reduces the proportion of services entry in the sample relative to the overall population. The relative entry and exit of startups versus existing firms in retail trade and construction are quite different. Our core estimations control for detailed industry differences, and we have further confirmed that our results are robust to excluding these sectors entirely.

${ }^{13}$ Dunne et al. (1989), Davis et al. (1996), and Glaeser and Kerr (2007) provide additional details on entry patterns in the manufacturing sector. Dumais et al. (2002) and Ellison et al. (2007) consider the agglomeration and coagglomeration of startup and existing firm expansion, respectively.
} 
entry rates of startups and expansion establishments. We then turn to dynamic tests and stacked regressions to focus on more stringent identification of the effect of banking deregulation on entry rates and entry sizes of startups relative to those of existing firms. Lastly, we consider establishment exits and the churning process using the empirical apparatus developed with the entry regressions.

Our results suggest that US banking deregulations reduced financing constraints and improved ex ante allocative efficiency. However, we also show that the deregulations substantially increased 'churning' of startups at the lower end of the size distribution. This more prominent finding suggests that reduced distortions in the US banking industry 'democratized' entry among startups in product markets. While some of these startups survived ex post to enable the process of creative destruction, much of the startup entry at the lower end of the size distribution was short-lived.

\subsection{Pre-Post Estimations of Entry Rates at the State-Year Level}

Our characterization of banking deregulations and entry rates begins with a simple panel data model at the state-year level. The estimation takes the form,

$$
\ln \left(B I R_{s t}^{T y p e}\right)=\phi_{s}+\tau_{t}+\beta_{T R A} T R A_{s t}+\beta_{T E R} T E R_{s t}+\varepsilon_{s t},
$$

where $\phi_{s}$ and $\tau_{t}$ are vectors of state and year fixed effects, respectively. The state effects control for fixed differences in entry rates across states due to factors like California's larger economic size. The year effects account for aggregate changes in entry rates over time that result from the business cycle, national policy changes, and so on. $B I R_{s t}$ is the total count of establishment births in the state-year cell for the indicated Type of firm: startups or existing firms. $T R A_{s t}$ and $T E R_{s t}$ model the intrastate and interstate banking deregulations, respectively. These indicator variables take a value of zero before the deregulations and one afterwards. As $B I R_{s t}$ is measured in logs, the $\beta$ coefficients measure the mean percentage increase in a state's births in the years following the deregulations. ${ }^{14}$

Panel A of Table 3 reports two regressions for three samples: all sectors, manufacturing only, and non-manufacturing. The first regression of each set considers startup entry rates, while the second regression focuses on the entry rates of new establishments opened by existing firms.

\footnotetext{
${ }^{14}$ The LBD is centered on March of each year. We thus date the reforms such that a passage of $T R A$ in 1987, for example, is coded as changing from 0 to 1 in 1988. We also include in each regression an interaction of the reforms with an indicator for an Economic Census year (i.e., 1977, 1982, 1987, 1992, 1997). In these years, more manpower is devoted to updating the business registry. As a result, longitudinal bumps occur in establishment entry counts for both types of firms. These interactions flexibly accommodate these shifts, although the interactions are insignificant and their coefficients are not informative. They can be excluded from the regressions without impacting the results. See Autor et al. (2007) for further details.
} 
These six regressions are all undertaken at the state-year level, so that the observation counts do not change across columns. We conservatively cluster standard errors at the state crosssectional level to address the serial correlation concerns for differences-in-differences estimations of Bertrand et al. (2004). Regressions are weighted by 1977-1985 total birth employment in the state cell; these weights do not change across entrant types. ${ }^{15}$

The specifications find that interstate banking deregulation is consistently associated with higher rates of startup entry. The coefficient elasticity of $6 \%$ is smaller, but similar in direction, to the 11\% elasticity of Black and Strahan (2002) using Dun \& Bradstreet incorporations. This positive response is evident for the whole sample and for the manufacturing and non-manufacturing subsamples. In unreported regressions examining sectors with the non-manufacturing subsample, stronger effects are found in wholesale and retail trade than in services. Nevertheless, a higher and statistically significant entry of startups following the interstate reform is evident for each sector analyzed. We find the intrastate banking deregulation is associated with higher entry rates in the manufacturing sector only. For non-manufacturers, which again comprise the bulk of the sample, no effect on entry is registered. ${ }^{16}$

These results suggest the interstate branch banking deregulations had a very large economic impact, leading to a $6 \%$ growth in startup birth rates. It is premature, however, to infer that these deregulations have a direct, causal benefit for entrepreneurship. Looking at the establishment entry rates of existing firms, the second regression of each set, we find a similar pattern of coefficients. The interstate banking deregulations are associated with higher entry rates that are statistically different from zero. Although the estimated elasticity of $4 \%$ for facility expansions is somewhat weaker than the $6 \%$ estimated for startups, we cannot reject the hypothesis that these elasticities are the same statistically.

\subsection{Dynamic Estimations of Entry Rates at the State-Year Level}

The pre-post estimations find higher entry rates for both startups and facility expansions around the interstate deregulations. It is possible, of course, that the deregulations were a response to greater levels of economic activity, including entrepreneurship, rather than the cause of them. For example, Kroszner and Strahan (1999) argue that the timing of the reforms are driven in part by the relative strength of banking interest groups that favored the deregulation. In order to examine this proposition more carefully, we turn to dynamic extensions of (1) that identify

\footnotetext{
${ }^{15}$ The weights afford population estimations of the impact of the banking deregulations. Similar results are obtained in unweighted regressions of these state-year panels.

${ }^{16}$ Black and Strahan (2002) find a 3\% elasticity in Dun \& Bradstreet incorporations to intrastate deregulations.
} 
whether the timing of product market entry following the deregulations is in a pattern consistent with a causal interpretation. ${ }^{17}$ These specifications take the form,

$$
\begin{aligned}
\ln \left(B I R_{s t}^{\text {Type }}\right)= & \phi_{s}+\tau_{t}+\sum_{q=-2}^{3} \beta_{T R A t+q} \Delta T R A_{s t+q}+\beta_{T R A t+4} T R A_{s t+4} \\
& +\sum_{q=-2}^{3} \beta_{T E R t+q} \Delta T E R_{s t+q}+\beta_{T E R t+4} T E R_{s t+4}+\varepsilon_{s t} .
\end{aligned}
$$

The post-reform indicators in (1), $T R A_{s t}$ and $T E R_{s t}$, are replaced by a series of lead and lag indicators. $T R A_{s t+4}$ and $T E R_{s t+4}$ take a unit value four or more years after the deregulation. The variables $\sum_{q=-2}^{3} \Delta T R A_{s t+q}$ and $\sum_{q=-2}^{3} \Delta T E R_{s t+q}$ are six separate indicator variables that span the six-year period from two years prior to the reform to three years after the reform. These six indicators take a unit value in their specific lead or lag year and are zero otherwise. Their coefficient pattern thus models the short-term dynamic effects around the reform, with $T R A_{s t+4}$ and $T E R_{s t+4}$ capturing outcomes four or more years after the deregulations.

Our main coefficients of interest are the long-term effects $\beta_{T R A t+4}$ and $\beta_{T E R t+4}$. The coefficients $\sum_{q=-2}^{3} \beta_{T R A t+q}$ and $\sum_{q=-2}^{3} \beta_{T E R t+q}$ focus on the timing of the reform and document whether the entry of new establishments following the reforms is consistent with a causal effect. In particular, we should be concerned if a strong lead effect is evident just before the deregulations are passed, regardless of whether it is heightened or diminished entry counts, as this would suggest an omitted factor is highly correlated with the timing of the deregulations. We also want to confirm that the dynamic pattern of effects leading into the long-term effects makes economic sense. The coefficient values for the leads and lags in (2) are relative to the period three years before the reforms and earlier; by comparison, the post indicators in (1) are relative to the period immediately before the reforms.

Panel B of Table 3 reports six specifications that again examine startups and facility expansions both within and outside of the manufacturing sector. To conserve space, we report in Table 3 a condensed form of (2) where the six single-year leads and lags are consolidated into three two-year increments. The long-term effects are still captured by the four-year lag coefficients $\beta_{T R A t+4}$ and $\beta_{\text {TERt+4 }}$. Appendix Table 2 reports the complete dynamic specifications for the full sample.

The dynamic specifications show a very consistent entry response for startups and facility expansions to the interstate banking deregulation. In both cases, the forward effect is of small

\footnotetext{
${ }^{17}$ The dynamic specifications identify whether the timing of product market entry is consistent with greater competition in the banking industry, even if the introduction of the competition itself was endogenous to the banking sector. Such a test has yet to be documented in a consistent way in the literature. Endogeneity in the banking sector can still be viewed as exogenous to the product markets, especially the relative impacts for startups versus facility expansions that we study later in this section. The stacked specifications ultimately remove all state-industry-year trends.
} 
magnitude and not statistically different from zero. After the reforms, the coefficients show an increasing pattern consistent with growing financial access due to greater bank competition. The long-run magnitudes again maintain the expected order, with startups having a greater elasticity than the expansion establishment formations of existing firms. No consistent effect is again evident for the intrastate deregulations.

A potential concern with these results is that they may be driven by unobserved changes in industry structure or similar factors that are correlated with changes in the structure of the banking industry. For example, changes in technology may be independently associated with structural changes in both sectors. It is important to note that all states but one moved from the control to the treatment group during our sample period, suggesting that the timing of any omitted factor would need to be closely correlated with the timing of the deregulations. Appendix Table 2 also shows that the results are robust to including linear state time trends. These linear trends center identification on the discontinuities surrounding the reforms. We further address these concerns below with our stacked framework.

The second and third sets of regressions in Panel B highlight that the long-run elasticities of entry in non-manufacturing sectors are higher than those in the manufacturing sector. Some may find this surprising given the perceived higher financial dependency of manufacturing. Two notes can be made. First, many industries within manufacturing (e.g., leather goods) are less dependent on external finance than those in trade or services; we test directly the financial dependency prediction later in this section and find some evidence for it. More importantly, manufacturing is experiencing stagnant employment trends during this period, while other sectors are expanding. It is not surprising that the elasticities of establishment entry to changes in financing constraints are weaker for a declining sector. For a hypothetical industry with no entrepreneurial enticement, the expected elasticity from the deregulations would be zero.

To verify that our results are being driven by enhanced bank competition following the deregulations, we also consider dynamic specifications that analyze how the US deregulations impacted the commercial banking industry itself. These estimations, available upon request, show a sharp increase in the number of out-of-state banks following the interstate deregulations. Moreover, a significant proportion of this growth was driven by large banks with an average of 500 or more employees over the period 1977-1985. These trends confirm deregulation's role in the descriptive statistics outlined in Table 1. The observed growth of out-of-state banks following the interstate deregulations is informative of the mechanism through which banking liberalizations impacted entry in the non-financial sector. Both factors follow the interstate deregulations in dynamically consistent patterns, with limited to no response to intrastate deregulations. Taken together, these results suggest that increased competition from out-of-state banks played a particularly important role in promoting entry of new establishments, both of new startups 
and of existing firms, following the interstate deregulations. ${ }^{18}$

\subsection{Stacked Estimations of Entry Rates at the State-Industry-Type- Year Level}

The state-year panel estimations provide us with two pieces of evidence for moving forward. First, we note that the most simple estimation highlights that interstate deregulations had a positive, significant effect on the entry of new establishments. Moreover, this entry response is dynamically consistent with the view that greater competition from out-of-state banks increased credit for startup firms. While this effect is stronger for startup establishments, we also noted the somewhat smaller, but still statistically significant, response for the entry of expansion establishments associated with existing firms. We cannot reject the hypothesis that the two entry elasticities are the same at the state-year level.

When discussing the dynamic specifications, we noted the potential for omitted variables to bias our estimations if the unmodeled factors are very tightly linked to the passage of the branch banking deregulations. While the dynamic specifications and the linear state time trends help mitigate this concern, we make additional progress in this section through a more stringent differences-in-differences specification. This estimation procedure directly contrasts the effect of the banking deregulations on startups with facility expansions by established firms. The empirical claim is that facility expansions can serve as an appropriate control group conditional on removing the aggregate differences documented in Figure 2. Panel B of Table 3 suggests that this strategy is reasonable. Similar to the startups, the facility expansions do not have a lead pattern prior to the interstate reforms; moreover, the dynamic growth in their coefficients is reasonable.

Aside from controlling for potential omitted variables, our identification strategy also has a useful substantive interpretation in that it teases out the differential response of startups to changes in banking deregulations over and above the heightened facility expansions of existing firms. Since startups are particularly dependent on banks for external finance, these results can also be interpreted as a technique for understanding how much more important changes in the structure of the banking industry are for entrepreneurship relative to existing firms.

With this comparison in mind, we move to a more stringent specification that exploits the full potential of the Census Bureau data. We calculate from the LBD entry counts by cells

\footnotetext{
${ }^{18}$ As in Table 1, we identify commercial bank establishments as SIC 602 . A particular advantage of the LBD data in this context is the ability to study the long-run effects of these reforms on the number and size of out-of-state banks. Following the Riegle-Neal Act of 1994, banks are not required to hold their assets locally in each subsidiary. Accordingly, prior studies using bank assets have been limited in their ability to draw inferences beyond 1994. Since the LBD focuses on establishment-level employment, it provides a consistent longitudinal metric before and after the Riegle-Neal Act.
} 
constructed on four dimensions: state, SIC2 industry, year, and type (i.e., startup or existing firm). Put another way, we stack the data so that both entry types are included in the same regression rather than in separate regressions; we also incorporate the industry dimension. Over 110k observations are created through this technique. We can easily relate this augmented specification, however, to the earlier state-year estimations through the specification,

$$
\begin{aligned}
\ln \left(B I R_{\text {sit }}^{\text {Type }}\right)= & \phi_{\text {si }}^{\text {Type }}+\tau_{t}^{\text {Type }}+\sum_{q=-2}^{3} \beta_{\text {TRAt }+q}^{\text {Startup }} \Delta T R A_{\text {st }+q}^{\text {Startup }}+\beta_{\text {TRAt }+4}^{\text {Startup }} T R A_{\text {st }+4}^{\text {Startup }} \\
& +\sum_{q=-2}^{3} \beta_{\text {TRAt }+q}^{\text {Existing }} \Delta T R A_{\text {st }+q}^{\text {Existing }}+\beta_{\text {TRAt }+4}^{\text {Existing }} T R A_{\text {st }+4}^{\text {Existing }} \\
& +\sum_{q=-2}^{3} \beta_{\text {TERt }+q}^{\text {Startup }} \Delta T E R_{\text {st }+q}^{\text {Startup }}+\beta_{\text {TERt }+4}^{\text {Startup }} T E R_{\text {st }+4}^{\text {Startup }} \\
& +\sum_{q=-2}^{3} \beta_{\text {TERt }+q}^{\text {Existing }} \Delta T E R_{\text {st }+q}^{\text {Existing }}+\beta_{\text {TERt }+4}^{\text {Existing }} T E R_{\text {st }+4}^{\text {Existing }}+\epsilon_{\text {sit }}^{\text {Type }} .
\end{aligned}
$$

In this specification, $\phi_{s i}^{\text {Type }}$ is a vector of state-industry-type cross-sectional fixed effects similar to state vector $\phi_{s}$ in (2). Likewise, $\tau_{t}^{\text {Type }}$ extends the earlier vector of year fixed effects $\tau_{t}$ to be by Type. These two extensions allow the startups and existing firms to have independent panel effects as in Table 3's separated regressions. The remainder of (3) interacts the dynamic TRA and TER deregulation indicators from (2) to be by Type. By interacting both Type forms, the main effect is dropped and the coefficients replicate the single Type specifications above. ${ }^{19}$

The first column of Table 4 shows this proposed similarity. The dependent variable is again the log establishment entry counts in constructed cells. The first block of coefficients is for the startup type interactions with the two sets of reforms; these coefficients are very close to the estimates in Column 1 of Table 3. The lower block shows interactions for expansions by existing firms; these parallel Column 2 of Table 3. These coefficients are estimated jointly, with standard errors conservatively clustered at the state-type level. The minor differences to Table 4 come from including the industry dimension, but the dynamic patterns and coefficient magnitudes are similar to the earlier estimates.

Columns 2 through 4 of Table 4 extend (3) to include state-industry-year fixed effects $\eta_{\text {sit }}$,

\footnotetext{
${ }^{19}$ Similar to the earlier specifications, we include interactions for Economic Census years and weight the regressions by the 1977-1985 birth employments in the state-industry cell. While all state-year observations have startup and facility expansions, this is not true at the industry level. To maintain a consistent observation count in log specifications, we recode a zero entry count as one and include unreported dummies for zero count observations by type. The results are robust to dropping these observations entirely; in general, these cells receive very small weight.
} 


$$
\begin{aligned}
\ln \left(B I R_{\text {sit }}^{\text {Type }}\right)= & \phi_{\text {si }}^{\text {Type }}+\tau_{t}^{\text {Type }}+\eta_{\text {sit }} \\
& +\sum_{q=-2}^{3} \beta_{\text {TRAt }+q}^{\text {Startup }} \Delta T R A_{\text {st }+q}^{\text {Startup }}+\beta_{\text {TRAt }+4}^{\text {Startup }} T R A_{\text {st }+4}^{\text {Startup }} \\
& +\sum_{q=-2}^{3} \beta_{\text {TERt }+q}^{\text {Startup }} \Delta T E R_{s t+q}^{\text {Startup }}+\beta_{\text {TERt }+4}^{\text {Startup }} T E R_{\text {st }+4}^{\text {Startup }}+\epsilon_{\text {sit }}^{\text {Type }} .
\end{aligned}
$$

As these additional $\eta_{\text {sit }}$ fixed effects saturate the model, the dynamic coefficients for startup firms become relative to the establishment expansions of existing firms. Indeed, this specification is only possible by contrasting types within a state-industry-year cell, and separate coefficients for expansion establishments are no longer estimated.

The $\eta_{\text {sit }}$ fixed effects fully absorb changes in local conditions at the state-industry level. They thus account for the state-year and industry-year dynamics typically modelled in this literature. $^{20}$ Moreover, the $\eta_{\text {sit }}$ fixed effects control for the unique outcomes of specialized stateindustry combinations like software in Silicon Valley and the automotive industry in Michigan. This modelling advantage goes well beyond long-term levels differences. It further captures longitudinal changes at the state-industry level in overall entry rates, sector sizes, and business volatilities.

From an econometric standpoint, this specification allows us to isolate the elasticity from more potential omitted factors. As omitted factors would need to operate within state-industry cells, this technique provides new confidence against endogeneity concerns. This structure also demonstrates the comparability of our count-based estimations and entry-rate formulations relative to local cell sizes. From a substantive perspective, this stacked specification directly contrasts the growth of startup entry following the banking reforms to the establishment expansions of existing firms. This allows us to better tease out the impact of the changing financial conditions for entrepreneurship specifically versus economic growth more generally.

Column 2's differential elasticity estimate of $11 \%$ for startups relative to the opening of new establishments by existing firms is our preferred estimation. This estimate is statistically different from zero; recall that this statistical difference could not be established with the earlier state-year estimations. Among states, California has the largest impact on the interstate findings, but excluding this state results in only a small elasticity decrease to $8 \%$ that remains statistically significant. Columns 3 and 4 report two other robustness checks, the first an unweighted specification and the second dropping the period after the passage of the Riegle-Neal

\footnotetext{
${ }^{20}$ It is important to note that cross-sectional fixed effects are also included. Estimations without the crosssectional controls can be biased by the non-proportional allocation of industries across states, even if state-year and industry-year controls are included.
} 
Act of 1994 that allowed national interstate branch banking. The continued positive elasticity and the dynamic pattern suggest that the interstate deregulations had a positive impact for entrepreneurship relative to existing businesses. More generally, it points to specific financing constraints faced by entrepreneurs that were in part eased by these reforms.

Table 4 again highlights that there was no consistent effect of the intrastate banking deregulations on entry rates. These results are consistent with Black and Strahan (2002) and also highlight that their finding that the intrastate banking deregulations had marginal effects on entry was not driven by compositional differences in industry growth across states. Given the high rates of entry subsequent to the interstate deregulations, the lack of entry following the intrastate reforms is somewhat puzzling. We discuss this, and related issues, in greater detail in Section 5 below.

Table 5 further examines whether differences across industries are consistent with our banking constraints and entrepreneurship hypothesis. If startups are more financially constrained, the relative entry elasticities of startups compared to facility expansions should be greater in industries that are more dependent on external finance compared to less dependent industries. We follow Rajan and Zingales (1998), Cetorelli and Strahan (2006), and Aghion et al. (2007) in constructing a metric of industry-level dependence on external finance. ${ }^{21}$ The higher coefficient magnitudes for financially dependent sectors support the theoretical prediction, although some of the long-term elasticities are not statistically different between the two industry groupings. The differences within manufacturing - the typical sector studied in these papers - are stronger than the overall differences.

Overall, the industry dimension again supports the interpretation of interstate banking reforms acting to increase startup entry relative to facility expansions. These results primarily serve as a robustness check and to relate our work to the literature. This test, however, is more stringent than has been identified in prior work on credit constraints. We have three differences: pre-post reforms, startups versus facility expansions, and industry-dependence on external finance.

\subsection{Stacked Estimations of Entry Size}

Having documented the effect of the banking reforms on the overall entry rates for startup establishments, we turn to the distribution of entry sizes for firms. Theoretical models suggest that even if potential entrepreneurs are not precluded from starting new businesses due to

\footnotetext{
${ }^{21}$ We compute a measure of external dependence at the SIC2 level through the universe of Compustat firms in the "Industrial Annual" database for 1990-2000. We then create an indicator variable for an industry being above or below the median external dependence that is interacted with the regressors. Main effects are absorbed into the cross-sectional fixed effects.
} 
financing constraints, they may still start firms that are smaller than optimal for the projects at hand (e.g., Evans and Jovanovic 1989). If indeed the increases in relative entry rates are an indication of financing constraints facing potential entrepreneurs, we may also find effects in the intensive margin of initial firm employment.

Empirically identifying the effect of changes in financing constraints on the intensive margin of entry is complicated by the fact that there are simultaneous changes in both the extensive and the intensive margins. The ideal estimations would compare entry sizes before and after the reforms for firms that would have entered regardless of the banking deregulations. In this case, average entry size could be an appropriate metric. The earlier estimations, however, document that greater entry is facilitated by the deregulations, and we do not have a way of distinguishing which firms would have entered in the counterfactual. This is particularly true at the lower end of the size distribution, where we might expect to see the strongest effects on both the intensive and extensive margins of greater financial access.

To clarify these issues, we first repeat the stacked specification with the vector of stateindustry-year effects (4) for different entry sizes. We group entering establishments into four size categories based upon employment in the year of entry: 1-5 employees, 6-20 employees, 21-100 employees, and over 100 employees. The coefficients on the banking reform indicators in these regressions estimate the relative elasticity of startup entry to facility expansions within each size grouping. The results of these regressions are reported in the first four columns of Table 6.

Table 6 shows that relative growth in startup entry rates following the interstate deregulations are particularly strong at the lower end of the entry-size distribution. The increased entry of firms with fewer than 20 employees offers the best indication of the extensive margin of entry. The greater relative increase in entry within the 6-20 employee category suggests that while firms entering at very small sizes may be able to substitute bank finance with personal savings and funds from friends and family, this is less likely to be true for those trying to enter at somewhat higher firm sizes (e.g., Fluck et al. 1998). The coefficient in this specification implies a $22 \%$ increase in the relative entry of the 6-20 employee category following the interstate deregulations. Although much weaker, there is also an indication of increased entry at even larger firm sizes, suggesting that the reforms may have affected the intensive margin by boosting the size at which firms enter. This entry pattern is therefore consistent with financing constraints impacting both extensive and intensive margins of entrepreneurship. ${ }^{22}$

We also undertake a second test in Column 5 of Table 6 that employs the longitudinal nature of the Census Bureau data. We first restrict the sample to the 1977-1996 period to allow us

\footnotetext{
${ }^{22}$ Table 6 finds more mixed evidence than the aggregate entry regressions regarding the impact of intrastate deregulations. There is some evidence that relative entry rates for startups, especially in the larger size categories, may have declined following these reforms.
} 
to observe entrants for three years after their foundings; we also condition the sample on cells where entry occurs. For each establishment that survives three years, we calculate its entry size relative to the maximum employment it achieves in its first three years of operation. We then calculate the mean of this entry-size ratio by state-industry-type-year cells. Examining the unweighted means across these cells, startup firms and facility expansions enter at $68 \%$ and $75 \%$ of their maximum three-year sizes, respectively.

These lower relative entry sizes for startups may directly reflect financing constraints on the intensive margin, but the differential may include other factors like increased caution due to greater uncertainty. To assess whether financing constraints play an important role, we test whether startups enter closer to their maximum three-year sizes after the banking deregulations. Using the stacked framework with the vector of state-industry-year effects (4), the estimation is again a comparison to the baseline provided by facility expansions. This approach provides a more direct metric of financing constraints on the intensive margin by looking withinestablishment rather than at the cross-section of entry. It is potentially limited, however, by the conditioning on survival for three years. ${ }^{23}$

Column 5 of Table 6 again finds no measurable impact on the intensive margin following the intrastate deregulations. Following the interstate deregulations, however, there was a $2 \%$ increase in the entry sizes of startups compared to the maximum sizes they achieved in the first three years of operation. This estimation is again a relative comparison to the responses of expansion establishments for existing firms, providing evidence that entrepreneurs in particular are able to enter closer to their optimal project sizes following the deregulations. While a full analysis of entry sizes requires a broader investigation of the firm-size distribution, this result again suggests that the effects of financing constraints for entrepreneurship are present on both the extensive and intensive entry margins.

\subsection{Stacked Estimations of Establishment Exit Rates and Churn}

We now turn to the impact of the banking deregulations on establishment exits and churn. One of the ways that banking deregulations are argued to facilitate the process of creative destruction is through improved allocative efficiency by moving capital away from poorly performing firms to better opportunities (e.g., Bertrand et al. 2007). Table 7 tests this hypothesis within the US by documenting exit rates across different parts of the establishment size distribution. As with

\footnotetext{
${ }^{23}$ In particular, startups have different hazard functions of failure relative to facility expansions, and this may introduce some bias in the mean ratios. Taking manufacturing as an example, about $50 \%$ of startups fail in their first three years of operation versus $40 \%$ of expansion establishments. The three-year window trades off this survival bias with allowing more time for new establishments to reach their desired size (e.g., due to internal cash flows or better external finance opportunities).
} 
Table 6, the coefficients reflect the relative increase or decline in exit rates for single-unit firms compared to establishments belonging to multi-unit firms.

Similar to the entry specifications, relative exits increased following the interstate deregulations, while no impact is evident with the intrastate reforms. Columns 2 and 3 of Table 7 document that exit rates for single-unit firms with 20 employees or fewer increased more than $20 \%$ compared to establishments belonging to multi-unit firms. The relative increase in startup exits with five employees or less, in fact, exceed the entry gains documented in Table 6. However, this is not due to a large, absolute decline in the number of small firms. Rather, as we document in Table 8, it is due to the dramatic increase in the number of very short-lived establishments at the lower end of the size distribution. In the growing US economy, firm starts are greater in number than firm closures throughout the period studied. Adding these churning establishments to these starts and exits results in a higher elasticity for exits.

Examining the upper end of the size distribution, the relative increase in exits for larger single-unit firms was substantially smaller than at the lower end. Moreover, the differences between single-unit and multi-unit establishments are only marginally significant statistically. The direction of these responses, however, do suggest that there was not a large-scale increase in the closure of poorly performing incumbent firms following the reforms. If this were true, exit rates for single-unit firms at the higher end of the size distribution would have been lower. This limited closure suggests that the dramatic increases in entry promoted by the deregulations likely resulted in much smaller changes in product market structure.

Table 8 brings these entry and exit results together. We separate entry of new establishments into those that survive more than three years (labeled longer-term entrants) and those that exit within three years of entry (labeled churn). Similar to the entry-size estimations, this sample is restricted to the 1977-1996 period to allow us to observe these outcomes.

Panel A demonstrates that longer-term entry following the interstate deregulations was fairly consistent across the entry-size distribution, with even the largest startup establishments experiencing a $10 \%$ increase in entry rates relative to facility expansions. This uniformity across the size distribution contrasts sharply with Table 6's skewness of overall entry towards the lower end of the size distribution. Since these large establishments are not as likely to be credit constrained on the extensive margin, these results are consistent with the view that allocative efficiency improved following the deregulations. That is, startup firms may have received financing for projects that they would not have prior to the deregulations because they were not 'insiders' or past clients of banks.

Panel B of Table 8 paints a more dramatic picture of the effects of the US banking deregulations. We find a $27 \%$ increase in churning for startups relative to existing firms following the 
interstate banking deregulations. Moreover, all of this churning increase came from firms that entered with 100 employees or fewer; no response is evident in the largest size category. ${ }^{24}$ This enormous increase in short-lived entry of small firms reconciles Table 6's skewness of overall entry towards the lower end of the size distribution with the uniformity of longer-term entry across the size distribution evident in Panel A of Table 8. This churning is further evident in Table 7's substantial growth in relative startup exits among firms with 20 employees or fewer.

This substantial increase in the entry of new establishments that fail within three years was not just a consequence of banks learning about different markets following the deregulations. The dynamic pattern suggests the churning effect grows after the deregulations to its highest level four or more years subsequent to the reform. This pattern also cannot be explained solely through a model of improved ex ante allocative efficiency on the part of banks. Instead, it suggests the deregulations also impact the process of creative destruction by 'democratizing' entry. Many, many more firms are started, some of which ultimately compete with and perhaps displace incumbents. A large number of these entrants, however, fail along the way.

The outcomes documented in Table 8 suggest that the net result of the US banking deregulations for the displacement of incumbents should be much weaker than the deregulation's impact on entry itself. We confirm this to be true in estimations that track the five or ten largest firms in 1980 for each state-industry cell over the sample period. We find that the interstate deregulations subsequently reduced these (log) incumbent market shares by approximately $0.5 \%$. While this effect is statistically significant, it is modest in economic magnitude. We also do not find measurable changes in Herfindahl indices of local industry structure. These estimations, available upon request, confirm that the dramatic increase in entry translated much less into changes in overall market leadership. ${ }^{25}$

\section{Conclusions}

Although there is a growing consensus that financial markets play an important role in driving economic growth, the micro-foundations behind this relationship are much less understood. The role of the banking industry in promoting entry through the efficient allocation of capital is of particular interest in this context, since there is increasing evidence that entrepreneurship plays a key role in facilitating innovation, impacting industry structure, and promoting economic growth.

\footnotetext{
${ }^{24}$ Some evidence of a lead effect exists for the smallest entrants following the interstate reform (Table 8, Panel B). The dynamic growth in coefficients, along with the general absence of lead effects on the entry and exit margins throughout this paper, mitigates this concern.

${ }^{25}$ This result differs from Bertrand et al. (2007) and is most likely due to better pre-reform banking conditions in the US compared to France.
} 
This paper examines how the increase in US banking competition through the deregulation of branch banking affected both the entry and survival of new establishments. We employ unique establishment-level data housed in the Census Bureau's Longitudinal Business Database. These micro-records facilitate several analyses that have not been undertaken in prior work. First, they allow us to compare the elasticity of entry for startups relative to the opening of new plants by existing firms. This technique controls for a greater set of omitted variables than prior work and isolates better the differential effect of financial-sector reforms for entrepreneurship. Second, the longitudinal structure enables examinations of how entry sizes were affected by the reforms, how entry and exit rates changed throughout the establishment size distribution, and how the survival rates of new ventures changed. This detail sheds more light on the mechanisms through which the deregulations impacted product market outcomes.

We do not find that the intrastate branch banking deregulations had a consistent, measured impact on either the entry rates or the entry sizes of new establishments. This was true for both startups and new establishments of existing firms. Our findings suggest that the intrastate branch banking deregulations did not affect the competitive environment of the local banking industry significantly, at least not in such a way that affected the net entry of new businesses.

On the other hand, the interstate deregulations had a strong, positive effect on the entry of startups compared to facility expansions by existing firms - an overall relative elasticity of $11 \%$. Among startups entering with 20 or fewer employees, the elasticity was even higher at 15-22\%. We also find evidence for growth in employment size at entry. Overall, our results suggest that the US deregulations reduced financing constraints and benefited startups more than existing firms. We also find some evidence consistent with the view that the deregulations improved allocative efficiency and somewhat reduced market shares of incumbents in product markets.

The more striking finding, however, is the growth in entrepreneurial churn at the lower end of the size distribution. We find that the entry of startup establishments that fail within three years increased as much as 30\% relative to new establishments of existing firms. While we are not yet able to distinguish between various explanations for this churning result ${ }^{26}$, it does highlight that the increase in banking competition seems to 'democratize' entry. The US banking deregulations facilitated the process of creative destruction not just by improved efficiency in the ex ante allocation of capital, but also through large-scale entry and subsequent closures of firms ex post.

The churning results also help reconcile the apparent contradictory findings of Black and Strahan (2002), who report large increases in entry rates of startups following the interstate

\footnotetext{
${ }^{26}$ Possible explanations include 1) lower financing constraints leads to weaker or more frivolous entry (e.g., Nanda 2007), 2) greater competition leads to higher failure rates, and 3) changes in the structure of banking in particular the loss of relationship banking - cause the churn.
} 
deregulations, and Cetorelli and Strahan (2006), who report a decline in the overall share of firms at the lower end of the firm-size distribution following the same reforms. We find that much of the entry at the lower end of the size distribution was short-lived. Our churning result thus helps explain why the large growth in entrepreneurship did not translate into larger changes in firm-size distribution.

Further, this paper sheds light on a possible reason why studies regarding the effects of banking competition on small businesses have had somewhat contradictory results. Consistent with the literature documenting a fall in credit extended to small businesses in the early 1990s (e.g., Berger et al. 2001; Zarutskie 2006), we also find a dip in startup activity over that period. Indeed, we further document how the relative growth of startups has lagged behind the growth of establishment openings by existing firms since the late 1970s (e.g., Davis et al. 2006). The positive elasticities of our panel estimations, however, suggest that increases in banking competition in part dampened national declines in startup entry in states that deregulated interstate branch banking relative to states that did not.

We see two areas in particular that warrant further study. First, the specific mechanisms through which the increased banking competition impacted entrepreneurial entry should be analyzed, especially the trade-off between greater competition and the benefits of relationship banking. The limited impact of the intrastate deregulations for entry rates, especially compared to the interstate deregulations, suggests that either the intrastate deregulations did not have enough bite or that there was something specific about the out-of-state banks that was important for promoting entrepreneurship. While some argue that the interstate deregulations enhanced the market for corporate control, others suggest that the main benefits of the interstate banking deregulation were the better allocation of credit and the better use of technology by the large, multi-state banks.

Understanding these mechanisms is an important question for future analysis, especially whether the reforms came at the expense of firms that rely more on soft information. For example, our findings that so many firms fail within the first three years, particularly at lower end of the size distribution, leaves open the possibility that there may in fact be a dark side to banking deregulations for entrepreneurial startups as suggested by Petersen and Rajan (1995). If changes in the organizational structure of banks following the deregulation led to different lending strategies (e.g., Berger et al. 2005; Sah and Stiglitz 1986) or lowered the ability for banks to evaluate projects because of weaker relationships, this may have had negative consequences for the survival of startups. On the other hand, the higher churning result may also imply greater efficiency in that banks were quicker to terminate weaker firms after the reforms (e.g., Gine and Love 2006).

Second, relating product market changes due to US banking deregulations to aggregate pro- 
ductivity growth is an important area of further investigation. Our results, and those of Black and Strahan (2002), emphasize that interstate banking deregulations had a much larger impact on the entry and exit of firms than the intrastate deregulations. A number of studies regarding aggregate productivity growth emphasize the importance of reallocations across firms versus within-establishment growth (e.g., Foster et al. 2001). These two literature strands are hard to reconcile, however, with Jayaratne and Strahan's (1996) finding that intrastate deregulations had a more consistent impact for US output and productivity growth than the interstate reforms. ${ }^{27}$ Perhaps our churning finding can bridge this gap. We intend to investigate this in future studies of how greater financial access and increased entrepreneurship might have long-term impacts on industrial structure and economic performance.

\footnotetext{
${ }^{27}$ This puzzle exists within panel estimations, like our work and Jayaratne and Strahan (1996), and also at the aggregate level. Davis et al. (2006) note that the aggregate US trend towards declining firm volatility from the 1970 s onward is difficult to reconcile with the large US aggregate productivity gains over the same period using standard Schumpeterian theories.
} 


\section{References}

[1] Aghion, P., T. Fally, and S. Scarpetta. 2007. "Credit constraints as a barrier to the entry and post-entry growth of firms." Economic Policy, pp. 731-79.

[2] Autor, D., W. Kerr, and A. Kugler. 2007. "Does employment protection reduce productivity? Evidence from U.S. states.” Economic Journal, 117:521, pp. 189-217.

[3] Banerjee, A. and E. Duflo. 2004. "Do firms want to borrow more? Testing credit constraints using a directed lending program." MIT Working Paper.

[4] Beck, T. and R. Levine. 2002. "Industry growth and capital allocation: Does having a market - or bank - based system matter?" Journal of Financial Economics, 64:2, pp. 14780 .

[5] Beck, T., R. Levine, and N. Loayza. 2000. "Finance and the sources of growth." Journal of Financial Economics, 58:1-2, pp. 261-300.

[6] Berger, A. N., A. K. Kashyap, and J. M. Scalise. 1995. "The transformation of the US banking industry. What a long, strange trip it's been." Brookings Papers on Economic Activity, 2, pp. 55-218.

[7] Berger, A. N., L. F. Klapper, and G. F. Udell. 2001. "The ability of banks to lend to informationally opaque small businesses." Journal of Banking \& Finance, 25:12, pp. 212767.

[8] Berger, A. N., N. H. Miller, M. A. Petersen, R. G. Rajan, and J. C. Stein. 2005. "Does function follow organizational form? Evidence from the lending practices of large and small banks." Journal of Financial Economics, 76:2, pp. 237-69.

[9] Berger, A. N. and G. F. Udell. 1995. "Relationship lending and lines of credit in small firm finance." Journal of Business, 68:3, pp. 351-81.

[10] Berger, A. N. and G. F. Udell. 2002. "Small business credit availability and relationship lending: The importance of bank organisational structure." Economic Journal, 112:477, pp. F32-F53.

[11] Bertrand, M., E. Duflo, and S. Mullainathan. 2004. "How much should we trust difference in differences estimates?" The Quarterly Journal of Economics, 119:1, pp. 249-75.

[12] Bertrand, M., A. Schoar, and D. Thesmar. 2007. "Banking deregulation and industry structure: Evidence from the French banking reforms of 1985." Journal of Finance, 62:2, pp. 597-628.

[13] Black, S. E. and P. E. Strahan. 2001. "The division of spoils: Rent sharing and discrimination in a regulated industry." American Economic Review, 91:4, pp. 814-31.

[14] Black, S. E. and P. E. Strahan. 2002. "Entrepreneurship and bank credit availability." Journal of Finance, 57:6, pp. 2807-33.

[15] Cabral, L. M. B. and J. Mata. 2003. "On the evolution of the firm size distribution: Facts and theory." American Economic Review, 93:4, pp. 1075-90.

[16] Cetorelli, N. 2004. "Real effects of bank competition." Journal of Money, Credit and Banking, 36:3, pp. 543-58.

[17] Cetorelli, N. and M. Gambera. 2001. "Banking market structure, financial dependence and growth: International evidence from industry data." Journal of Finance, 56:2, pp. 617-48. 
[18] Cetorelli, N. and P. E. Strahan. 2006. "Finance as a barrier to entry: Bank competition and industry structure in local U.S. markets." Journal of Finance, 61:1, pp. 437-61.

[19] Davis, S., J. Haltiwanger, R. Jarmin, and J. Miranda. 2006. "Volatility and dispersion in business growth rates: Publicly traded versus privately held firms." NBER Working Paper 12354.

[20] Davis, S., J. Haltiwanger, and S. Schuh. 1996. Job Creation and Destruction, Cambridge: MIT Press.

[21] Dumais, G., G. Ellison, and E. Glaeser. 2002. "Geographic concentration as a dynamic process." Review of Economics and Statistics, 84, pp. 193-204.

[22] Dunne, T., M. Roberts, and L. Samuelson. 1989, "Patterns of firm entry and exit in U.S. manufacturing industries." The RAND Journal of Economics, 19, pp. 495-515.

[23] Ellison, G., E. Glaeser, and W. Kerr. 2007. "What causes industry agglomeration? Evidence from coagglomeration patterns." NBER Working Paper 13068.

[24] Erel, I. 2006. "The effect of bank mergers on loan prices: Evidence from the U.S." Working Paper.

[25] Evans, D. S. and B. Jovanovic. 1989. "An estimated model of entrepreneurial choice under liquidity constraints." Journal of Political Economy, 97:4, pp. 808-27.

[26] Fazzari, S. M., R. G. Hubbard, and B. C. Petersen. 1988. "Financing constraints and corporate investment." Brookings Papers on Economic Activity, 1, pp. 141-95.

[27] Fluck, Z., D. Holtz-Eakin, and H. S. Rosen. 1998. "Where does the money come from? The financing of small entrepreneurial enterprises." NYU Stern Working Paper.

[28] Foster, L., J. Haltiwanger, and C.J. Krizan. 2001. "Aggregate productivity growth: Lessons from the microeconomic evidence." In Dean E., M. Harper, and C. Hutten, ed. New Developments in Productivity Analysis, Chicago: University of Chicago Press.

[29] Gentry, W. and G. Hubbard. 2000. "Entrepreneurship and household saving." NBER Working Paper 7894.

[30] Gine, X. and I. Love. 2006. "Do reorganization costs matter for efficiency? Evidence from a bankruptcy reform in Colombia." World Bank Policy Research Working Paper 3970.

[31] Glaeser, E. and W. Kerr. 2007. "Local industrial conditions and entrepreneurship: How much of the spatial distribution can we explain?" Working Paper.

[32] Hurst, E. and A. Lusardi. 2004. "Liquidity constraints, household wealth, and entrepreneurship." Journal of Political Economy, 112:2, pp. 319-47.

[33] Janicki, H. and E. Prescott. 2006. "Changes in the size distribution of U.S. banks: 19602005." Federal Reserve Bank of Richmond Economic Quarterly, 92:4, pp. 291-316.

[34] Jarmin, R. and J. Miranda. 2002. "The longitudinal business database." CES Working Paper.

[35] Jayaratne, J. and P. E. Strahan. 1996. "The finance-growth nexus: Evidence from bank branch deregulation." Quarterly Journal of Economics, 111:3, pp. 639-70. 
[36] Kane, E. J. 1996. "De Jure interstate banking: Why only now?" Journal of Money, Credit and Banking, 28:2, pp. 141-61.

[37] Kaplan, S. N. and L. Zingales. 1997. "Do investment-cash flow sensitivities provide useful measures of financing constraints?" Quarterly Journal of Economics, 112:1, pp. 169-215.

[38] Kaplan, S. N. and L. Zingales. 2000. "Investment-cash flow sensitivities are not valid measures of financing constraints." Quarterly Journal of Economics, 115:2, pp. 707-12.

[39] King, R. G. and R. Levine. 1993a. "Finance and growth - Schumpeter might be right." Quarterly Journal of Economics, 108:3, pp. 717-37.

[40] King, R. G. and R. Levine. 1993b. "Finance, entrepreneurship, and growth - Theory and evidence." Journal of Monetary Economics, 32:3, pp. 513-42.

[41] Kroszner, R. S. and P. E. Strahan. 1999. "What drives deregulation? Economics and politics of the relaxation of bank branching restrictions." Quarterly Journal of Economics, 114:4, pp. 1437-67.

[42] Laeven, L. 2000. "Does financial liberalization relax financing constraints on firms?" World Bank Working Paper 2467.

[43] Levine, R. 1997. "Financial development and economic growth: Views and agenda." Journal of Economic Literature, 35:2, pp. 688-726.

[44] Levine, R., N. Loayza, and T. Beck. 2000. "Financial intermediation and growth: Causality and causes." Journal of Monetary Economics, 46:1, pp. 31-77.

[45] Moyen, N. 2004. "Investment-cash flow sensitivities: Constrained versus unconstrained firms." Journal of Finance, 59:5, pp. 2061-92.

[46] Nanda, R. 2007. "Cost of external finance and selection into entrepreneurship." HBS Working Paper.

[47] Paravisini, D. 2005. "Constrained banks and constrained borrowers: The effect of bank liquidity on the availability of credit." Working Paper.

[48] Petersen, M. A. and R. G. Rajan. 1994. "The benefits of lending relationships - Evidence from small business data." Journal of Finance, 49:1, pp. 3-37.

[49] Petersen, M. A. and R. G. Rajan. 1995. "The effect of credit market competition on lending relationships." Quarterly Journal of Economics, 110:2, pp. 407-43.

[50] Rajan, R. G. and L. Zingales. 1998. "Financial dependence and growth." American Economic Review, 88:3, pp. 559-86.

[51] Rajan, R. G. and L. Zingales. 2003. "The great reversals: The politics of financial development in the twentieth century." Journal of Financial Economics, 69:1, pp. 5-50.

[52] Sah, R. K. and J. E. Stiglitz. 1986. "The architecture of economic systems: Hierarchies and polyarchies." American Economic Review, 76:4, pp. 716-27.

[53] Stein, J. C. 2002. "Information production and capital allocation: Decentralized versus hierarchical firms." Journal of Finance, 57:5, pp. 1891-921.

[54] Zarutskie, R. 2006. "Evidence on the effects of bank competition on firm borrowing and investment." Journal of Financial Economics, 81, 503-37. 
Fig. 1: U.S. Branch Banking Deregulations

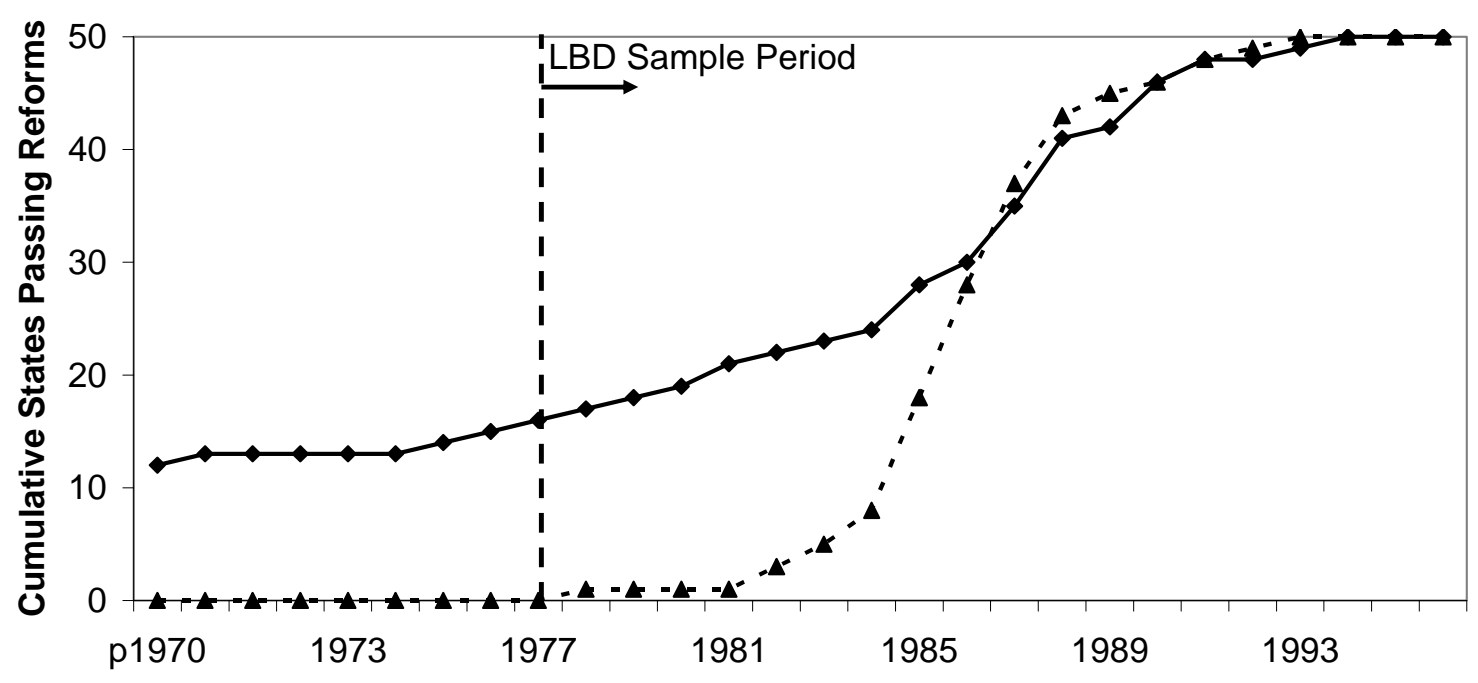

$\multimap-$ Intrastate Deregulations - ^- Interstate Deregulations

Fig. 2: Relative Birth Counts by Type

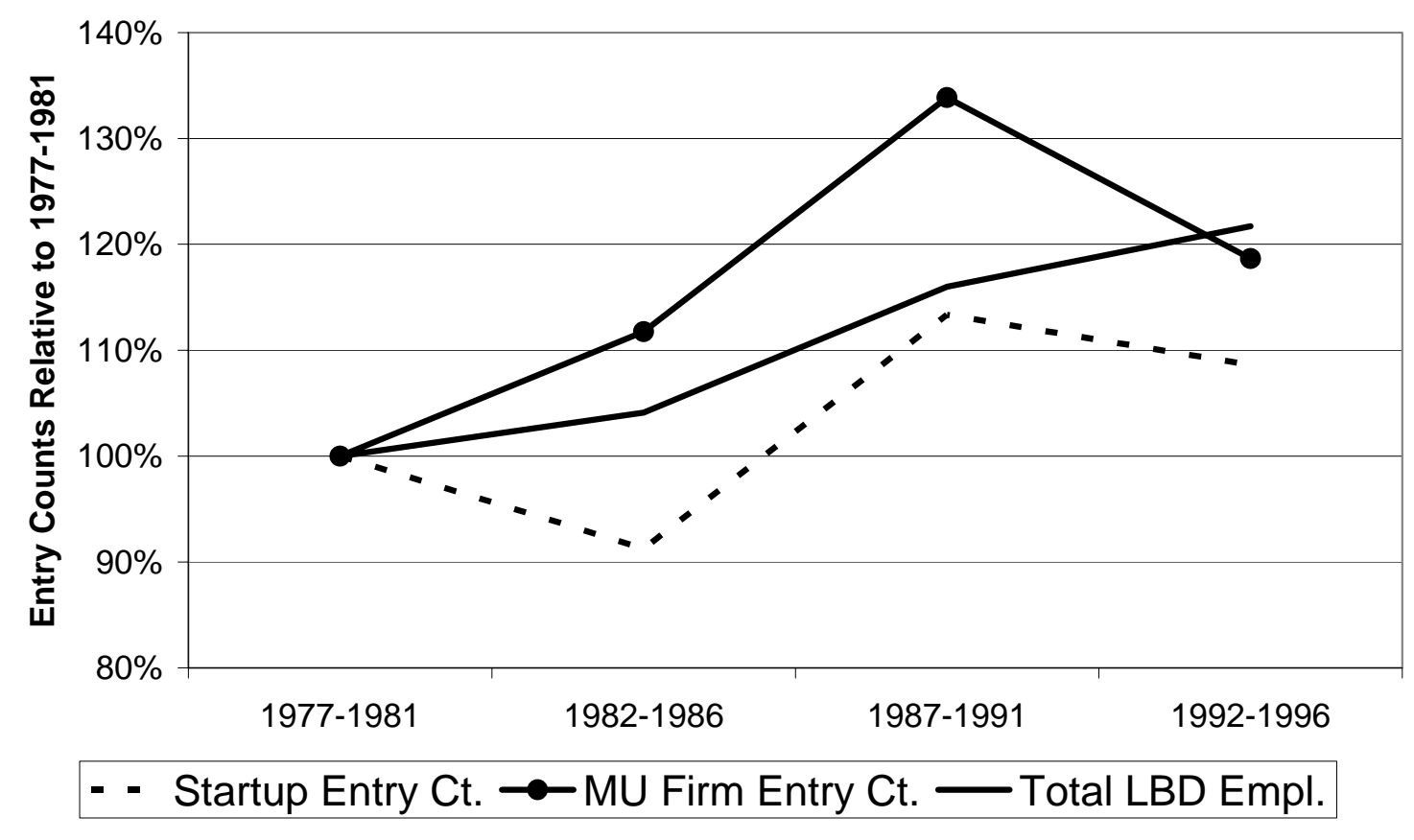


Fig. 3: Distribution of Entry Sizes

All Sectors, By Type of Entrant

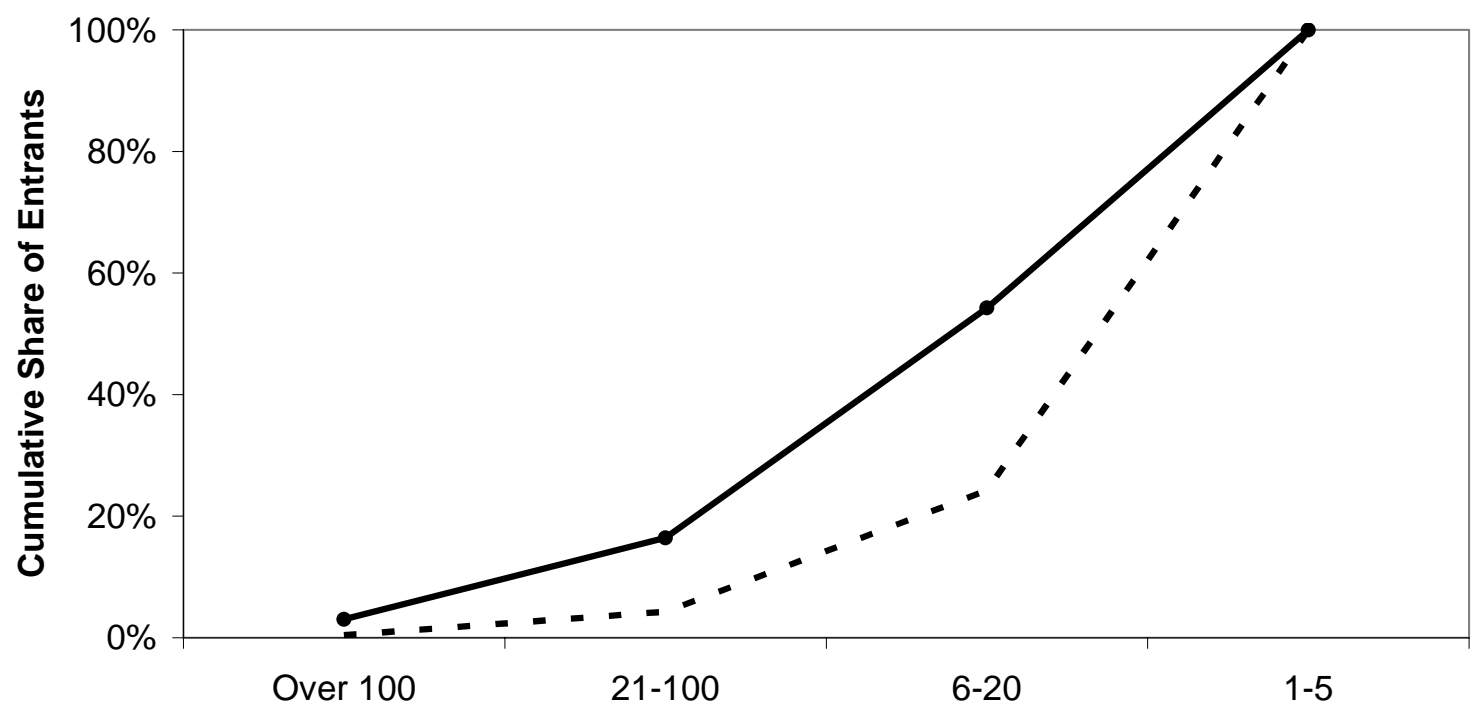

Number of Employees in the First Year of Operation

$\rightarrow$ Multi-Unit Firms - - Startup Firms

Fig. 4: Distribution of Entry Sizes

Manufacturing Sector, By Type of Entrant

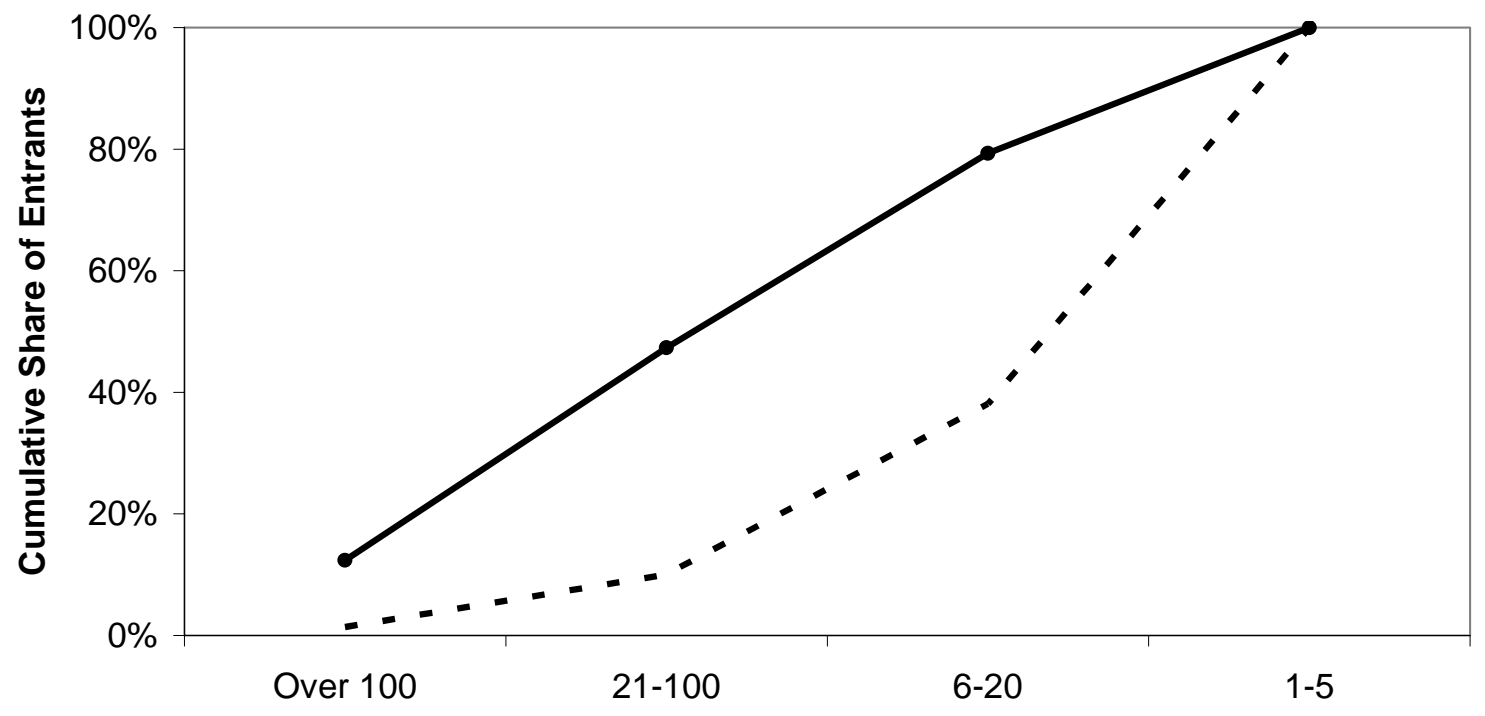

Number of Employees in the First Year of Operation

$\rightarrow$ Multi-Unit Firms - - Startup Firms 
Table 1A: LBD-Based Descriptive Statistics on U.S. Banking Industry

\begin{tabular}{lcc}
\hline & 1977 & 1994 \\
\hline Total Number of Banking Organizations & 12,810 & 8,547 \\
\% with less than 50 employees & $79.0 \%$ & $69.8 \%$ \\
\% with branches in multiple states & $0.3 \%$ & $2.6 \%$ \\
Total Number of Banking Branches & 38,231 & 64,155 \\
\% owned by banks with 500+ employees & $49.5 \%$ & $65.9 \%$ \\
\% owned by banks with mean 500+ employees before 1985 & $52.4 \%$ & $62.4 \%$ \\
\% owned by banks originally located in other states & $2.4 \%$ & $25.3 \%$ \\
\hline
\end{tabular}

Notes: Descriptive details taken from LBD for SIC 602 (1987 classifications).

Table 1B: Asset-Based Descriptive Statistics on U.S. Banking Industry

\begin{tabular}{lcc}
\hline & 1979 & 1994 \\
\hline Total Number of Banking Organizations & 12,463 & 7,926 \\
$\quad$ Small Banks (less than \$100m in assets) & $80.3 \%$ & $71.1 \%$ \\
Real Gross Industry Assets (in trillions of 1994 dollars) & 3.26 & 4.02 \\
Industry Assets in Megabanks (more than \$100b in assets) & $9 \%$ & $19 \%$ \\
Industry Assets in Small Banks (less than \$100m in assets) & $14 \%$ & $7 \%$ \\
\hline
\end{tabular}

Source: Berger et al. (2001). 
Table 2: LBD Descriptive Statistics on U.S. Product Markets

\begin{tabular}{|c|c|c|c|c|c|c|c|c|c|}
\hline & \multicolumn{3}{|c|}{ Entering Establishments } & \multicolumn{3}{|c|}{ Exiting Establishments } & \multicolumn{3}{|c|}{ Churning Establishments } \\
\hline & $\begin{array}{c}\text { All } \\
\text { Entrants }\end{array}$ & $\begin{array}{c}\text { New } \\
\text { Startups }\end{array}$ & $\begin{array}{c}\text { Multi-Unit } \\
\text { Facilities }\end{array}$ & $\begin{array}{c}\text { All } \\
\text { Exits }\end{array}$ & $\begin{array}{l}\text { Single-Unit } \\
\text { Firms }\end{array}$ & $\begin{array}{c}\text { Multi-Unit } \\
\text { Facilities }\end{array}$ & $\begin{array}{c}\text { All } \\
\text { Entrants }\end{array}$ & $\begin{array}{c}\text { New } \\
\text { Start-ups }\end{array}$ & $\begin{array}{c}\text { Multi-Unit } \\
\text { Facilities }\end{array}$ \\
\hline Mean Annual Counts & 407,783 & 335,807 & 71,976 & 362,376 & 299,668 & 62,708 & 173,371 & 153,519 & 19,852 \\
\hline Mean Annual Empl. & $3,811,409$ & $2,081,801$ & $1,729,608$ & $3,454,544$ & $1,919,014$ & $1,535,530$ & & & \\
\hline Share of Entrants & & & & & & & $43 \%$ & $46 \%$ & $28 \%$ \\
\hline \multicolumn{10}{|l|}{ Size Distribution } \\
\hline 1-5 Employees & $70.3 \%$ & $75.9 \%$ & $44.4 \%$ & $71.3 \%$ & $76.1 \%$ & $48.6 \%$ & $76.2 \%$ & $79.3 \%$ & $51.9 \%$ \\
\hline 6-20 Employees & $22.8 \%$ & $19.8 \%$ & $36.6 \%$ & $21.5 \%$ & $19.2 \%$ & $32.5 \%$ & $18.8 \%$ & $17.1 \%$ & $31.6 \%$ \\
\hline 21-100 Employees & $5.8 \%$ & $3.8 \%$ & $14.9 \%$ & $6.1 \%$ & $4.3 \%$ & $14.6 \%$ & $4.4 \%$ & $3.2 \%$ & $13.1 \%$ \\
\hline \multicolumn{10}{|l|}{ Sector Distribution } \\
\hline Manufacturing & $9 \%$ & $9 \%$ & $6 \%$ & $9 \%$ & $9 \%$ & $9 \%$ & $8 \%$ & $9 \%$ & $7 \%$ \\
\hline Services & $28 \%$ & $29 \%$ & $22 \%$ & $27 \%$ & $28 \%$ & $20 \%$ & $29 \%$ & $30 \%$ & $23 \%$ \\
\hline Wholesale Trade & $12 \%$ & $11 \%$ & $17 \%$ & $12 \%$ & $11 \%$ & $19 \%$ & $11 \%$ & $10 \%$ & $18 \%$ \\
\hline Retail Trade & $25 \%$ & $22 \%$ & $42 \%$ & $27 \%$ & $25 \%$ & $40 \%$ & $25 \%$ & $23 \%$ & $38 \%$ \\
\hline Mining & $1 \%$ & $1 \%$ & $1 \%$ & $1 \%$ & $1 \%$ & $1 \%$ & $1 \%$ & $1 \%$ & $2 \%$ \\
\hline Construction & $17 \%$ & $20 \%$ & $1 \%$ & $17 \%$ & $20 \%$ & $2 \%$ & $18 \%$ & $20 \%$ & $2 \%$ \\
\hline Transportation & $7 \%$ & $7 \%$ & $10 \%$ & $7 \%$ & $6 \%$ & $9 \%$ & $7 \%$ & $7 \%$ & $10 \%$ \\
\hline \multicolumn{10}{|l|}{ Geographic Distribution } \\
\hline Northeast & $19 \%$ & $20 \%$ & $17 \%$ & $20 \%$ & $20 \%$ & $18 \%$ & $18 \%$ & $18 \%$ & $17 \%$ \\
\hline South & $36 \%$ & $35 \%$ & $37 \%$ & $35 \%$ & $35 \%$ & $35 \%$ & $37 \%$ & $37 \%$ & $37 \%$ \\
\hline
\end{tabular}

Notes: Descriptive statistics for establishments outside of the financial sector in the Longitudinal Business Database. Entry and exit statistics are calculated over $1977-1998$.

Churning entrants, defined as new establishments failing within three years of entry, are calculated over 1977-1996. The size distribution of churning entrants is calculated in their first year of operation. Jarmin and Miranda (2002) describe the construction of the LBD. The LBD includes incorporated firms only; unincorporated businesses and partnerships are not considered in this study. Sectors not included in the LBD are agriculture, forestry and fishing, public administration, and private households. We also exclude the US postal service, restaurants and food stores, hospitals, education services, and social services. Incomplete LBD records require dropping 25 state-year files: 1978 (12 states), 1983 (4), 1984 (4), 1985 (1), 1986 (1), 1989 (1), and 1993 (2). 
Table 3: Banking Deregulations and Establishment Entry Rates in U.S. Product Markets

\begin{tabular}{|c|c|c|c|c|c|}
\hline \multicolumn{2}{|c|}{ All Sectors } & \multicolumn{2}{|c|}{ Manufacturing } & \multicolumn{2}{|c|}{ Non-Manufacturing } \\
\hline $\begin{array}{l}\text { Single-Unit } \\
\text { Start-Ups }\end{array}$ & $\begin{array}{l}\text { Multi-Unit } \\
\text { Establish. } \\
\text { Openings }\end{array}$ & $\begin{array}{l}\text { Single-Unit } \\
\text { Start-Ups }\end{array}$ & $\begin{array}{c}\text { Multi-Unit } \\
\text { Establish. } \\
\text { Openings }\end{array}$ & $\begin{array}{l}\text { Single-Unit } \\
\text { Start-Ups }\end{array}$ & $\begin{array}{l}\text { Multi-Unit } \\
\text { Establish. } \\
\text { Openings }\end{array}$ \\
\hline (1) & (2) & (3) & (4) & (5) & (6) \\
\hline
\end{tabular}

A. Pre-Post Specifications for Log Establishment Birth Counts by State-Year

$\begin{array}{lcccccc}\text { Intra-State Banking } & 0.000 & -0.015 & 0.037 & 0.023 & -0.004 & -0.020 \\ \text { Dereg. Post Indicator } & (0.025) & (0.035) & (0.018) & (0.042) & (0.027) & (0.036) \\ \text { Inter-State Banking } & 0.060 & 0.037 & 0.059 & 0.039 & 0.059 & 0.040 \\ \text { Dereg. Post Indicator } & (0.019) & (0.018) & (0.021) & (0.028) & (0.021) & (0.019)\end{array}$

B. Dynamic Specifications for Log Establishment Birth Counts by State-Year

$\begin{array}{lcccccc}\text { Intra-State Banking } & -0.039 & -0.015 & 0.025 & 0.032 & -0.046 & -0.022 \\ \text { Dereg. Fwd. 1-2 Yrs } & (0.034) & (0.024) & (0.022) & (0.039) & (0.037) & (0.024) \\ \text { Intra-State Banking } & -0.041 & -0.018 & 0.012 & -0.003 & -0.047 & -0.020 \\ \text { Dereg. Lag 0-1 Yr } & (0.046) & (0.046) & (0.036) & (0.062) & (0.048) & (0.046) \\ \text { Intra-State Banking } & -0.045 & 0.012 & 0.011 & 0.115 & -0.052 & 0.003 \\ \text { Dereg. Lag 2-3 Yrs } & (0.035) & (0.043) & (0.031) & (0.051) & (0.036) & (0.046) \\ \text { Intra-State Banking } & -0.029 & 0.004 & 0.001 & -0.001 & -0.032 & 0.002 \\ \text { Dereg. Lag 4+ Yrs } & (0.048) & (0.050) & (0.034) & (0.055) & (0.050) & (0.052) \\ & & & & & 0.023 & -0.024 \\ \text { Inter-State Banking } & 0.025 & -0.021 & 0.052 & 0.027 & (0.034) & (0.027) \\ \text { Dereg. Fwd. 1-2 Yrs } & (0.032) & (0.026) & (0.025) & (0.044) & 0.057 & 0.004 \\ \text { Inter-State Banking } & 0.059 & 0.005 & 0.082 & 0.061 & (0.035) & (0.030) \\ \text { Dereg. Lag 0-1 Yr } & (0.033) & (0.029) & (0.027) & (0.049) & 0.173 & 0.083 \\ \text { Inter-State Banking } & 0.170 & 0.078 & 0.137 & 0.071 & (0.039) & (0.036) \\ \text { Dereg. Lag 2-3 Yrs } & (0.038) & (0.035) & (0.031) & (0.056) & 0.031 \\ \text { Inter-State Banking } & 0.223 & 0.129 & 0.141 & 0.071 & (0.064) & 0.141 \\ \text { Dereg. Lag 4+ Yrs } & (0.056) & (0.046) & (0.041) & (0.064) & (0.060) & (0.048)\end{array}$

Notes: Panel estimations consider log counts of establishment births taken from the LBD for 1977-1998. Sectors and types of firms for dependent variables are indicated in the column headers. Single-unit start-ups are new firm formations. Multi-unit establishment openings are new establishment openings by existing firms. The sample includes all states and DC from 1977-1998, excepting 25 stateyear cells where LBD files are not available, for 1097 observations per regression. Regressions include state and year fixed effects. Regressions include unreported interactions of explanatory indicators with a Census year dummy. Regressions are weighted by average birth employment in cells from 1977-1985. Standard errors are conservatively clustered at the state cross-sectional level.

Pre-Post specifications compare annual entry rates before and after the state-level banking deregulation indicated. Dynamic specifications replace the post deregulation indicators with a series of leads and lags for each reform. To conserve space, leads and lags are consolidated into two-year increments extending from two years prior to the deregulations to four or more years after the deregulations. The coefficient values for the dynamic leads and lags are relative to the period three years before the reforms and earlier. Appendix Table 2 presents the complete lag structure for Columns 1-2 and extensions to include linear state time trends. 
Table 4: Stacked Specifications of Establishment Entry Rates in U.S. Product Markets

\begin{tabular}{ccccc}
\hline & Regr. With & Column 1 & Column 2 & Column 2 \\
ST-SIC-TYPE & Adding & Without & Weights & Sample to \\
& \& TYPE-YR FE & ST-SIC-YR & FE & Prior to 1994 \\
\cline { 2 - 4 } & $(1)$ & $(2)$ & $(4)$ \\
\hline
\end{tabular}

Dependent Variable is Log Establishment Birth Counts by State-SIC2-Type-Year

Single-Unit Start-Ups Interactions:

Intra-State Banking Dereg. Fwd. 1-2 Yrs Intra-State Banking Dereg. Lag 0-1 Yrs Intra-State Banking Dereg. Lag 2-3 Yrs Intra-State Banking Dereg. Lag 4+ Yrs Inter-State Banking Dereg. Fwd. 1-2 Yrs Inter-State Banking Dereg. Lag 0-1 Yrs Inter-State Banking Dereg. Lag 2-3 Yrs Inter-State Banking Dereg. Lag 4+ Yrs

Existing Firm Expansions Interactions: Intra-State Banking Dereg. Fwd. 1-2 Yrs Intra-State Banking Dereg. Lag 0-1 Yrs Intra-State Banking Dereg. Lag 2-3 Yrs Intra-State Banking Dereg. Lag 4+ Yrs

Inter-State Banking Dereg. Fwd. 1-2 Yrs Inter-State Banking Dereg. Lag 0-1 Yrs Inter-State Banking Dereg. Lag 2-3 Yrs Inter-State Banking Dereg. Lag 4+ Yrs
$-0.037(0.030)$
$-0.044(0.039)$
$-0.055(0.027)$
$-0.035(0.039)$
$0.028(0.028)$
$0.054(0.027)$
$0.152(0.033)$
$0.202(0.041)$
$-0.021(0.048)$
$0.026(0.044)$
$0.009(0.052)$
$0.001(0.031)$
$0.016(0.036)$
$0.079(0.036)$
$0.096(0.049)$
$-0.021(0.030)$

$$
\begin{array}{r}
-0.016(0.023) \\
-0.022(0.035) \\
-0.082(0.036) \\
-0.045(0.029) \\
0.027(0.031) \\
0.038(0.033) \\
0.073(0.039) \\
0.106(0.038)
\end{array}
$$

Absorbed

Absorbed
$-0.006(0.022)$

$-0.007(0.031)$

$-0.051(0.034)$

0.021 (0.029)

$0.031(0.031)$

$0.050(0.033)$

$0.089(0.040)$

$0.122(0.045)$

Absorbed

Observations

111,894

111,894

111,894

85,884

Notes: Panel estimations consider log birth counts of establishments taken from the LBD for 1977-1998. Annual cells are constructed by State-SIC2-Type, where Type includes entering start-ups and existing firms. Banking deregulations are dynamically modeled through indicator variables as in Table 3 . All regressions include cross-sectional State-SIC2-Type and longitudinal Type-Year fixed effects. Columns 2-4 further include State-SIC2-Year fixed effects that remove all local conditions common across Types. In these saturated models, the start-up response is estimated relative to facility expansions, and separate coefficients for expansion establishments are no longer estimated or reported. Regressions include unreported dummies for cells with zero births and unreported interactions of explanatory variables with a Census year dummy. Regressions are weighted by average birth employment in cells from 1977-1985. Standard errors are conservatively clustered at the cross-sectional State-Type level. 
Table 5: Financial Dependency in Stacked Specifications of Establishment Entry

\begin{tabular}{ccccc}
\hline & Regr. With & Column 1 & Column 1 & Column 1 \\
ST-SIC-TYPE & Without & Restricting & Sample to & Sestricting \\
\& TYPE-YR & Weights & Prior to 1994 & Manufacturing \\
\cline { 2 - 5 } & \& ST-SIC-YR FE & $(2)$ & (3) & $(4)$ \\
\hline
\end{tabular}

Dependent Variable is Log Establishment Birth Counts by State-SIC2-Type-Year

Financially Dependent Sectors

Single-Unit Start-Ups Interactions:

Intra-State Banking Dereg. Fwd. 1-2 Yrs

Intra-State Banking Dereg. Lag 0-1 Yrs

$\begin{array}{lr}-0.029(0.023) & 0.003(0.026) \\ -0.023(0.036) & 0.036(0.031) \\ -0.077(0.037) & 0.003(0.029) \\ -0.043(0.031) & -0.037(0.025) \\ 0.032(0.031) & 0.052(0.025) \\ 0.005(0.030) & 0.014(0.034) \\ 0.063(0.039) & 0.040(0.031) \\ 0.118(0.039) & 0.098(0.037)\end{array}$

$-0.018(0.023)$

$0.070(0.054)$

Intra-State Banking Dereg. Lag 2-3 Yrs

Intra-State Banking Dereg. Lag 4+ Yrs

Inter-State Banking Dereg. Fwd. 1-2 Yrs

Inter-State Banking Dereg. Lag 0-1 Yrs

Inter-State Banking Dereg. Lag 2-3 Yrs

$0.098(0.037)$

$-0.001(0.032)$

$0.046(0.052)$

$-0.037(0.035) \quad-0.174(0.059)$

$0.034(0.034) \quad 0.004(0.060)$

Inter-State Banking Dereg. Lag 4+ Yrs

$0.118(0.039)$

$0.035(0.030)$

$0.051(0.063)$

$0.017(0.031) \quad 0.092(0.064)$

$0.076(0.041) \quad 0.140(0.083)$

$0.141(0.046) \quad 0.224(0.087)$

Non-Financially Dependent Sectors

Single-Unit Start-Ups Interactions:

Intra-State Banking Dereg. Fwd. 1-2 Yrs

Intra-State Banking Dereg. Lag 0-1 Yrs

$\begin{array}{rr}0.012(0.036) & -0.015(0.029) \\ -0.018(0.039) & -0.021(0.029) \\ -0.088(0.041) & -0.100(0.030) \\ -0.048(0.032) & -0.075(0.022) \\ 0.019(0.035) & 0.004(0.022) \\ 0.109(0.044) & 0.029(0.031) \\ 0.093(0.041) & 0.026(0.028) \\ 0.078(0.038) & 0.021(0.033)\end{array}$

$0.021(0.036)$
$-0.017(0.041)$
$-0.078(0.052)$
$-0.006(0.048)$
$0.026(0.034)$
$0.123(0.043)$
$0.115(0.044)$
$0.082(0.055)$

$0.007(0.039)$

$-0.003(0.060)$

$-0.066(0.055)$

$-0.033(0.041)$

Intra-State Banking Dereg. Lag 4+ Yrs

Inter-State Banking Dereg. Fwd. 1-2 Yrs Inter-State Banking Dereg. Lag 0-1 Yrs Inter-State Banking Dereg. Lag 2-3 Yrs Inter-State Banking Dereg. Lag 4+ Yrs

111,894

111,894

85,884

$0.027(0.038)$

$-0.031(0.058)$

0.014 (0.071)

$-0.031(0.107)$

Observations

Notes: See Table 4. Additional interactions taken for financially dependent sectors versus non-financially dependent sectors. Financial dependence is defined through Compustat as described in the text. 
Table 6: Stacked Specifications of Entry Size Distribution in U.S. Product Markets

Births by Establishment Size Category

\begin{tabular}{cccc}
\hline Births with & Births with & Births with & Births with \\
1-5 Empl. & 6-20 Empl. & 21-100 Empl. & 101+ Empl.
\end{tabular}

(2)

(3)

Regressions of Birth

Entry Size Relative to

Max Size in First 3 Yrs

Dependent Variable is Log Establishment Birth Counts by State-SIC2-Type-Year (Col. 1-4)

Single-Unit Start-Ups Interactions:

Intra-State Banking Dereg. Fwd. 1-2 Yrs Intra-State Banking Dereg. Lag 0-1 Yrs Intra-State Banking Dereg. Lag 2-3 Yrs Intra-State Banking Dereg. Lag 4+ Yrs

Inter-State Banking Dereg. Fwd. 1-2 Yrs Inter-State Banking Dereg. Lag 0-1 Yrs Inter-State Banking Dereg. Lag 2-3 Yrs Inter-State Banking Dereg. Lag 4+ Yrs

Observations

$\begin{array}{rr}-0.032(0.028) & -0.009(0.032) \\ 0.005(0.032) & -0.056(0.040) \\ -0.099(0.041) & -0.075(0.038) \\ -0.034(0.036) & -0.067(0.037) \\ 0.037(0.029) & 0.064(0.038) \\ 0.052(0.026) & 0.096(0.030) \\ 0.114(0.034) & 0.148(0.040) \\ 0.148(0.046) & 0.223(0.042)\end{array}$

\author{
$-0.007(0.039)$ \\ $-0.034(0.051)$ \\ $-0.110(0.058)$ \\ $-0.059(0.048)$ \\ $0.063(0.046)$ \\ $0.108(0.065)$ \\ $0.138(0.048)$ \\ $0.097(0.045)$
}

$-0.001(0.008)$
$0.002(0.009)$
$0.005(0.007)$
$0.003(0.009)$
$0.000(0.008)$
$0.002(0.008)$
$0.014(0.008)$
$0.022(0.011)$

111,894

\section{(5)}

Notes: See Table 4. All regressions include cross-sectional State-SIC2-Type and longitudinal Type-Year fixed effects. Regressions further include State-SIC2-Year fixed effects that remove all local conditions common across Types. In these saturated models, the start-up response is estimated relative to facility expansions, and separate coefficients for expansion establishments are no longer estimated or reported. Columns 1-4 repeat the full stacked specification (Column 2 of Table 4) with births in different size categories. Column 5 substitutes the mean ratio of entry size relative to the maximum size achieved in the first three years of operation. These entry size ratios are calculated at the establishment level and are conditional on survival for three years. Unweighted means from the underlying distributions are calculated for each state-industrytype-year cell. 
Table 7: Stacked Specifications of Exit Size Distribution in U.S. Product Markets

\begin{tabular}{|c|c|c|c|c|c|}
\hline & \multirow{3}{*}{$\begin{array}{c}\text { All } \\
\text { Exits }\end{array}$} & \multicolumn{4}{|c|}{ Exits by Establishment Size Category } \\
\hline & & Exits with & Exits with & Exits with & Exits with \\
\hline & & 1-5 Empl. & 6-20 Empl. & 21-100 Empl. & 101+ Empl. \\
\hline & $(1)$ & $(2)$ & (3) & $(4)$ & $(5)$ \\
\hline & \multicolumn{5}{|c|}{ Dependent Variable is Log Establishment Exit Counts by State-SIC2-Type-Year } \\
\hline \multicolumn{6}{|l|}{ Single-Unit Start-Ups Interactions: } \\
\hline Intra-State Banking Dereg. Fwd. 1-2 Yrs & $-0.023(0.033)$ & $-0.002(0.035)$ & $-0.038(0.041)$ & $-0.007(0.046)$ & $-0.011(0.056)$ \\
\hline Intra-State Banking Dereg. Lag 0-1 Yrs & $-0.057(0.042)$ & $-0.050(0.047)$ & $-0.066(0.049)$ & $-0.036(0.043)$ & $-0.034(0.065)$ \\
\hline Intra-State Banking Dereg. Lag 2-3 Yrs & $-0.091(0.047)$ & $-0.103(0.057)$ & $-0.084(0.044)$ & $-0.060(0.055)$ & $-0.111(0.078)$ \\
\hline Intra-State Banking Dereg. Lag 4+ Yrs & $-0.036(0.029)$ & $-0.028(0.026)$ & $-0.045(0.038)$ & $-0.034(0.042)$ & $0.001(0.048)$ \\
\hline Inter-State Banking Dereg. Fwd. 1-2 Yrs & $0.001(0.023)$ & $0.003(0.021)$ & $0.011(0.022)$ & $-0.007(0.026)$ & $0.047(0.049)$ \\
\hline Inter-State Banking Dereg. Lag 0-1 Yrs & $0.038(0.030)$ & $0.054(0.028)$ & $0.053(0.035)$ & $0.017(0.044)$ & $0.028(0.067)$ \\
\hline Inter-State Banking Dereg. Lag 2-3 Yrs & $0.091(0.045)$ & $0.125(0.046)$ & $0.111(0.058)$ & $0.054(0.060)$ & $0.064(0.064)$ \\
\hline Inter-State Banking Dereg. Lag 4+ Yrs & $0.172(0.054)$ & $0.203(0.064)$ & $0.210(0.067)$ & $0.082(0.072)$ & $0.091(0.055)$ \\
\hline Observations & 111,894 & 111,894 & 111,894 & 111,894 & 111,894 \\
\hline
\end{tabular}

Notes: See Table 4. All regressions include cross-sectional State-SIC2-Type and longitudinal Type-Year fixed effects. Regressions further include State-SIC2-Year fixed effects that remove all local conditions common across Types. In these saturated models, the start-up response is estimated relative to facility expansions, and separate coefficients for expansion establishments are no longer estimated or reported. 
Table 8: Entry Rates by Long-Term Survivors versus Churning in U.S. Product Markets

\begin{tabular}{|c|c|c|c|c|c|}
\hline & \multirow[b]{2}{*}{$\begin{array}{c}\text { All } \\
\text { Births }\end{array}$} & \multicolumn{4}{|c|}{ Births by Establishment Size Category } \\
\hline & & $\begin{array}{l}\text { Births with } \\
\text { 1-5 Empl. }\end{array}$ & $\begin{array}{l}\text { Births with } \\
\text { 6-20 Empl. }\end{array}$ & $\begin{array}{l}\text { Births with } \\
\text { 21-100 Empl. }\end{array}$ & $\begin{array}{l}\text { Births with } \\
\text { 101+ Empl. }\end{array}$ \\
\hline & $(1)$ & $(2)$ & (3) & $(4)$ & (5) \\
\hline & \multicolumn{5}{|c|}{ A. Entrants that Survive More Than Three Years (Long-Term) } \\
\hline \multicolumn{6}{|l|}{ Single-Unit Start-Ups Interactions: } \\
\hline Intra-State Banking Dereg. Fwd. 1-2 Yrs & $-0.015(0.020)$ & $-0.017(0.022)$ & $-0.020(0.035)$ & $-0.060(0.038)$ & $-0.048(0.043)$ \\
\hline Intra-State Banking Dereg. Lag 0-1 Yrs & $-0.006(0.027)$ & $0.032(0.026)$ & $-0.052(0.036)$ & $-0.046(0.037)$ & $-0.060(0.040)$ \\
\hline Intra-State Banking Dereg. Lag 2-3 Yrs & $-0.050(0.035)$ & $-0.042(0.032)$ & $-0.046(0.034)$ & $-0.013(0.040)$ & $-0.056(0.045)$ \\
\hline Intra-State Banking Dereg. Lag 4+ Yrs & $-0.020(0.034)$ & $0.023(0.037)$ & $-0.042(0.038)$ & $-0.031(0.036)$ & $-0.033(0.056)$ \\
\hline Inter-State Banking Dereg. Fwd. 1-2 Yrs & $0.044(0.033)$ & $0.044(0.036)$ & $0.053(0.039)$ & $0.059(0.046)$ & $0.047(0.032)$ \\
\hline Inter-State Banking Dereg. Lag 0-1 Yrs & $0.057(0.030)$ & $0.055(0.034)$ & $0.079(0.030)$ & $0.051(0.040)$ & $0.092(0.028)$ \\
\hline Inter-State Banking Dereg. Lag 2-3 Yrs & $0.086(0.039)$ & $0.121(0.044)$ & $0.128(0.038)$ & $0.092(0.061)$ & $0.118(0.041)$ \\
\hline Inter-State Banking Dereg. Lag 4+ Yrs & $0.078(0.039)$ & $0.099(0.054)$ & $0.169(0.045)$ & $0.054(0.059)$ & $0.102(0.069)$ \\
\hline \multirow[t]{2}{*}{ Observations } & 101,490 & 101,490 & 101,490 & 101,490 & 101,490 \\
\hline & \multicolumn{5}{|c|}{ B. Entrants that Survive Three Years or Less (Churn) } \\
\hline \multicolumn{6}{|l|}{ Single-Unit Start-Ups Interactions: } \\
\hline Intra-State Banking Dereg. Fwd. 1-2 Yrs & $-0.005(0.032)$ & $-0.019(0.037)$ & $0.021(0.038)$ & $-0.005(0.030)$ & $-0.009(0.050)$ \\
\hline Intra-State Banking Dereg. Lag 0-1 Yrs & $-0.020(0.040)$ & $-0.007(0.031)$ & $-0.030(0.046)$ & $0.019(0.050)$ & $-0.038(0.073)$ \\
\hline Intra-State Banking Dereg. Lag 2-3 Yrs & $-0.112(0.044)$ & $-0.080(0.032)$ & $-0.071(0.044)$ & $-0.037(0.036)$ & $-0.115(0.065)$ \\
\hline Intra-State Banking Dereg. Lag 4+ Yrs & $-0.040(0.046)$ & $0.002(0.040)$ & $-0.045(0.044)$ & $-0.022(0.035)$ & $-0.043(0.062)$ \\
\hline Inter-State Banking Dereg. Fwd. 1-2 Yrs & $0.063(0.029)$ & $0.063(0.021)$ & $0.098(0.032)$ & $0.050(0.040)$ & $0.022(0.049)$ \\
\hline Inter-State Banking Dereg. Lag 0-1 Yrs & $0.091(0.039)$ & $0.093(0.024)$ & $0.106(0.035)$ & $0.019(0.042)$ & $0.055(0.072)$ \\
\hline Inter-State Banking Dereg. Lag 2-3 Yrs & $0.148(0.048)$ & $0.147(0.035)$ & $0.208(0.051)$ & $0.094(0.052)$ & $0.051(0.083)$ \\
\hline Inter-State Banking Dereg. Lag 4+ Yrs & $0.267(0.056)$ & $0.258(0.049)$ & $0.338(0.067)$ & $0.170(0.050)$ & $-0.024(0.055)$ \\
\hline Observations & 101,490 & 101,490 & 101,490 & 101,490 & 101,490 \\
\hline
\end{tabular}

Notes: See Table 4. All regressions include cross-sectional State-SIC2-Type and longitudinal Type-Year fixed effects. Regressions further include State-SIC2-Year fixed effects that remove all local conditions common across Types. In these saturated models, the start-up response is estimated relative to facility expansions, and separate coefficients for expansion establishments are no longer estimated or reported. Panel A looks at birth rates of establishments that survive more than three years, while Panel B looks at birth rates of establishments that fail within three years of entry. 
App. Table 1: Timing of State Branch Banking Deregulations

\begin{tabular}{|c|c|c|c|}
\hline State & $\begin{array}{c}\text { Intrastate de novo } \\
\text { Deregulation }\end{array}$ & $\begin{array}{c}\text { Intrastate M\&A } \\
\text { Deregulation }\end{array}$ & $\begin{array}{c}\text { Interstate } \\
\text { Deregulation }\end{array}$ \\
\hline Alabama & 1990 & 1981 & 1987 \\
\hline Alaska & 1970 & 1970 & 1982 \\
\hline Arizona & 1970 & 1970 & 1986 \\
\hline Arkansas & Not deregulated & 1994 & 1989 \\
\hline California & 1970 & 1970 & 1987 \\
\hline Colorado & Not deregulated & 1991 & 1988 \\
\hline Connecticut & 1988 & 1980 & 1983 \\
\hline Delaware & 1970 & 1970 & 1988 \\
\hline District of Columbia & 1970 & 1970 & 1985 \\
\hline Florida & 1988 & 1988 & 1985 \\
\hline Georgia & Not deregulated & 1983 & 1985 \\
\hline Hawaii & 1986 & 1986 & Not deregulated \\
\hline Idaho & 1970 & 1970 & 1985 \\
\hline Illinois & 1993 & 1988 & 1986 \\
\hline Indiana & 1991 & 1989 & 1986 \\
\hline Iowa & Not deregulated & Not deregulated & 1991 \\
\hline Kansas & 1990 & 1987 & 1992 \\
\hline Kentucky & Not deregulated & 1990 & 1984 \\
\hline Louisiana & 1988 & 1988 & 1987 \\
\hline Maine & 1975 & 1975 & 1978 \\
\hline Maryland & 1970 & 1970 & 1985 \\
\hline Massachusetts & 1984 & 1984 & 1983 \\
\hline Michigan & 1988 & 1987 & 1986 \\
\hline Minnesota & Not deregulated & 1993 & 1986 \\
\hline Mississippi & 1989 & 1986 & 1988 \\
\hline Missouri & 1990 & 1990 & 1986 \\
\hline Montana & Not deregulated & 1990 & 1993 \\
\hline Nebraska & Not deregulated & 1985 & 1990 \\
\hline Nevada & 1970 & 1970 & 1985 \\
\hline New Hampshire & 1987 & 1987 & 1987 \\
\hline New Jersey & Not deregulated & 1977 & 1986 \\
\hline New Mexico & 1991 & 1991 & 1989 \\
\hline New York & 1976 & 1976 & 1982 \\
\hline North Carolina & 1970 & 1970 & 1985 \\
\hline North Dakota & Not deregulated & 1987 & 1991 \\
\hline Ohio & 1989 & 1979 & 1985 \\
\hline Oklahoma & Not deregulated & 1988 & 1987 \\
\hline Oregon & 1985 & 1985 & 1986 \\
\hline Pennsylvania & 1990 & 1982 & 1986 \\
\hline Rhode Island & 1970 & 1970 & 1984 \\
\hline South Carolina & 1970 & 1970 & 1986 \\
\hline South Dakota & 1970 & 1970 & 1988 \\
\hline Tennessee & 1990 & 1985 & 1985 \\
\hline Texas & 1988 & 1988 & 1987 \\
\hline Utah & 1981 & 1981 & 1984 \\
\hline Vermont & 1970 & 1970 & 1988 \\
\hline Virginia & 1987 & 1978 & 1985 \\
\hline Washington & 1985 & 1985 & 1987 \\
\hline West Virginia & 1987 & 1987 & 1988 \\
\hline Wisconsin & 1990 & 1990 & 1987 \\
\hline Wyoming & Not deregulated & 1988 & 1987 \\
\hline
\end{tabular}

Source: Jayaratne and Strahan (1996). Deregulations prior to 1970 are listed as 1970. 
App. Table 2: Complete Dynamic Specifications for Table 3

\begin{tabular}{|c|c|c|c|c|}
\hline & \multicolumn{2}{|c|}{ All Sectors } & \multicolumn{2}{|c|}{ Adding Linear State Time Trends } \\
\hline & $\begin{array}{l}\text { Single-Unit } \\
\text { Start-Ups }\end{array}$ & $\begin{array}{c}\text { Multi-Unit } \\
\text { Establish. } \\
\text { Openings }\end{array}$ & $\begin{array}{l}\text { Single-Unit } \\
\text { Start-Ups }\end{array}$ & $\begin{array}{l}\text { Multi-Unit } \\
\text { Establish. } \\
\text { Openings }\end{array}$ \\
\hline & $(1)$ & $(2)$ & (3) & $(4)$ \\
\hline & \multicolumn{4}{|c|}{ Dependent Variable is Log Est. Birth Counts by State-Year } \\
\hline $\begin{array}{l}\text { Intra-State Banking } \\
\text { Dereg. Fwd. } 2 \text { Yrs }\end{array}$ & $\begin{array}{c}0.006 \\
(0.023)\end{array}$ & $\begin{array}{l}-0.049 \\
(0.029)\end{array}$ & $\begin{array}{c}0.001 \\
(0.019)\end{array}$ & $\begin{array}{l}-0.045 \\
(0.030)\end{array}$ \\
\hline $\begin{array}{l}\text { Intra-State Banking } \\
\text { Dereg. Fwd. } 1 \text { Yrs }\end{array}$ & $\begin{array}{l}-0.055 \\
(0.041)\end{array}$ & $\begin{array}{c}0.003 \\
(0.027)\end{array}$ & $\begin{array}{l}-0.070 \\
(0.041)\end{array}$ & $\begin{array}{c}0.004 \\
(0.033)\end{array}$ \\
\hline $\begin{array}{l}\text { Intra-State Banking } \\
\text { Dereg. Change }\end{array}$ & $\begin{array}{l}-0.038 \\
(0.043)\end{array}$ & $\begin{array}{l}-0.016 \\
(0.035)\end{array}$ & $\begin{array}{l}-0.057 \\
(0.044)\end{array}$ & $\begin{array}{l}-0.013 \\
(0.046)\end{array}$ \\
\hline $\begin{array}{l}\text { Intra-State Banking } \\
\text { Dereg. Lag } 1 \mathrm{Yr}\end{array}$ & $\begin{array}{l}-0.047 \\
(0.048)\end{array}$ & $\begin{array}{l}-0.017 \\
(0.057)\end{array}$ & $\begin{array}{l}-0.073 \\
(0.053)\end{array}$ & $\begin{array}{l}-0.027 \\
(0.062)\end{array}$ \\
\hline $\begin{array}{l}\text { Intra-State Banking } \\
\text { Dereg. Lag } 2 \text { Yrs }\end{array}$ & $\begin{array}{l}-0.061 \\
(0.043)\end{array}$ & $\begin{array}{c}0.002 \\
(0.051)\end{array}$ & $\begin{array}{l}-0.085 \\
(0.051)\end{array}$ & $\begin{array}{l}-0.005 \\
(0.059)\end{array}$ \\
\hline $\begin{array}{l}\text { Intra-State Banking } \\
\text { Dereg. Lag } 3 \text { Yrs }\end{array}$ & $\begin{array}{l}-0.023 \\
(0.039)\end{array}$ & $\begin{array}{c}0.029 \\
(0.043)\end{array}$ & $\begin{array}{l}-0.049 \\
(0.060)\end{array}$ & $\begin{array}{c}0.014 \\
(0.060)\end{array}$ \\
\hline $\begin{array}{l}\text { Intra-State Banking } \\
\text { Dereg. Lag 4+ Yrs }\end{array}$ & $\begin{array}{l}-0.029 \\
(0.050)\end{array}$ & $\begin{array}{c}0.006 \\
(0.051)\end{array}$ & $\begin{array}{l}-0.067 \\
(0.058)\end{array}$ & $\begin{array}{c}0.010 \\
(0.065)\end{array}$ \\
\hline $\begin{array}{l}\text { Inter-State Banking } \\
\text { Dereg. Fwd. } 2 \text { Yrs }\end{array}$ & $\begin{array}{c}0.008 \\
(0.032)\end{array}$ & $\begin{array}{l}-0.019 \\
(0.027)\end{array}$ & $\begin{array}{c}0.035 \\
(0.034)\end{array}$ & $\begin{array}{l}-0.019 \\
(0.024)\end{array}$ \\
\hline $\begin{array}{l}\text { Inter-State Banking } \\
\text { Dereg. Fwd. } 1 \text { Yrs }\end{array}$ & $\begin{array}{c}0.062 \\
(0.041)\end{array}$ & $\begin{array}{l}-0.018 \\
(0.031)\end{array}$ & $\begin{array}{c}0.099 \\
(0.042)\end{array}$ & $\begin{array}{l}-0.012 \\
(0.031)\end{array}$ \\
\hline $\begin{array}{l}\text { Inter-State Banking } \\
\text { Dereg. Change }\end{array}$ & $\begin{array}{c}0.043 \\
(0.036)\end{array}$ & $\begin{array}{c}0.003 \\
(0.035)\end{array}$ & $\begin{array}{c}0.078 \\
(0.035)\end{array}$ & $\begin{array}{l}-0.004 \\
(0.034)\end{array}$ \\
\hline $\begin{array}{l}\text { Inter-State Banking } \\
\text { Dereg. Lag } 1 \mathrm{Yr}\end{array}$ & $\begin{array}{c}0.106 \\
(0.036)\end{array}$ & $\begin{array}{c}0.012 \\
(0.032)\end{array}$ & $\begin{array}{c}0.144 \\
(0.039)\end{array}$ & $\begin{array}{l}-0.001 \\
(0.036)\end{array}$ \\
\hline $\begin{array}{l}\text { Inter-State Banking } \\
\text { Dereg. Lag } 2 \text { Yrs }\end{array}$ & $\begin{array}{c}0.168 \\
(0.041)\end{array}$ & $\begin{array}{c}0.067 \\
(0.036)\end{array}$ & $\begin{array}{c}0.206 \\
(0.047)\end{array}$ & $\begin{array}{c}0.050 \\
(0.039)\end{array}$ \\
\hline $\begin{array}{l}\text { Inter-State Banking } \\
\text { Dereg. Lag } 3 \text { Yrs }\end{array}$ & $\begin{array}{c}0.226 \\
(0.047)\end{array}$ & $\begin{array}{c}0.112 \\
(0.036)\end{array}$ & $\begin{array}{c}0.263 \\
(0.058)\end{array}$ & $\begin{array}{c}0.088 \\
(0.048)\end{array}$ \\
\hline $\begin{array}{l}\text { Inter-State Banking } \\
\text { Dereg. Lag 4+ Yrs }\end{array}$ & $\begin{array}{c}0.258 \\
(0.060)\end{array}$ & $\begin{array}{c}0.144 \\
(0.049)\end{array}$ & $\begin{array}{c}0.278 \\
(0.078)\end{array}$ & $\begin{array}{c}0.098 \\
(0.067)\end{array}$ \\
\hline
\end{tabular}

Notes: See Table 3. 